\title{
Seasonal fluctuations of photosynthetic parameters for light use efficiency models and the impacts on gross primary production estimation
}

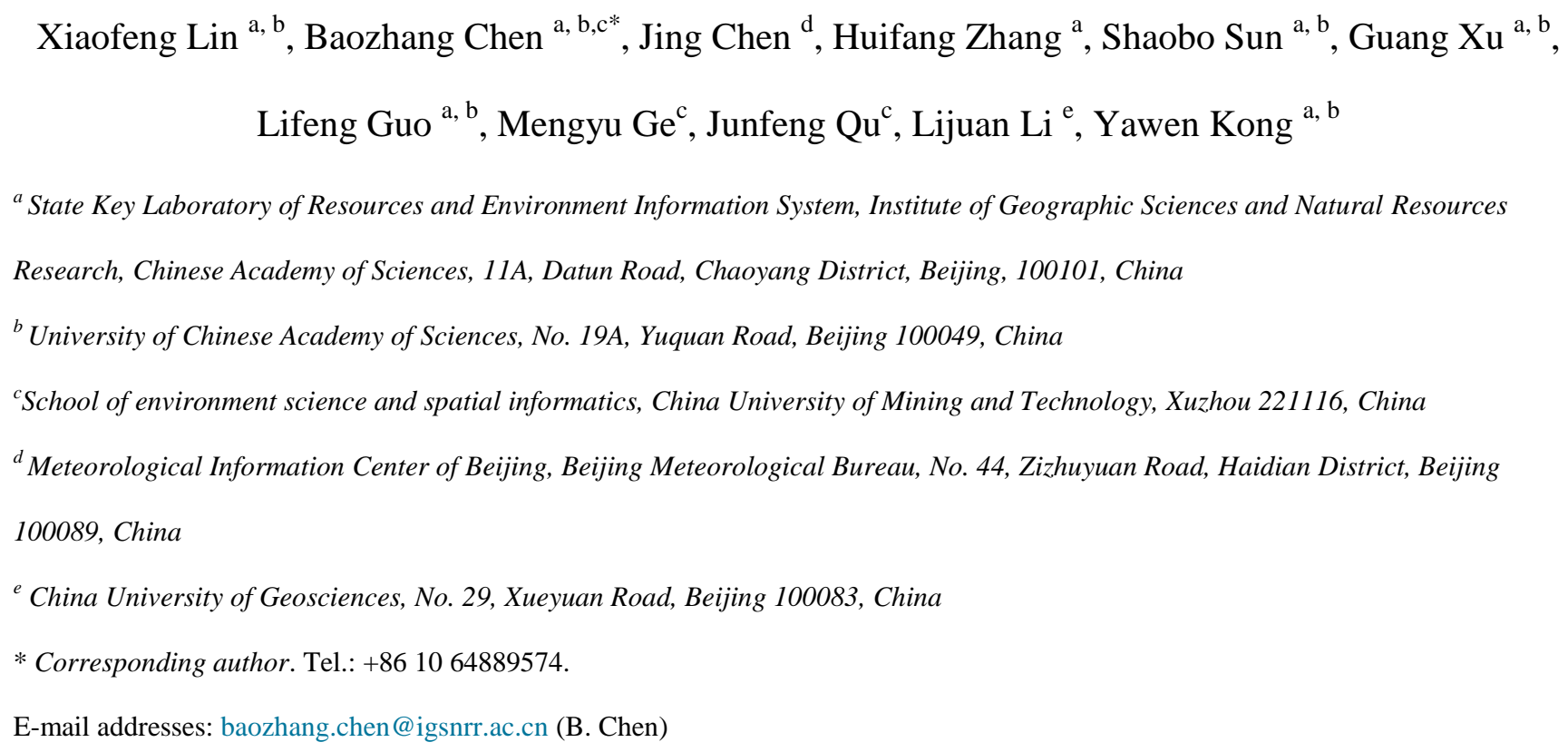




\section{Abstract}

How parameterization improves Light-use efficiency (LUE) models by taking into account the seasonal variations of the maximum LUE $\left(\varepsilon_{\max }\right)$ has been rarely investigated. The LUE models include two categories which are the one-leaf LUE model (SL-LUE) and the two-leaf LUE model (TL-LUE) with separation of sunlit and shaded leaves $\left(\varepsilon_{m s u}\right.$ and $\varepsilon_{m s h}$ ). In this study, the SL-LUE and TL-LUE models were parameterized for 46 towers (176 site-years data) representing eighteen typical plant functional types (PFTs) by using the Metropolis-Hasting algorithm at monthly time scales. The results indicate that the maximum LUE parameters varied seasonally for most PFTs having a significant positive linear correlation with leaf area index (LAI) and ambient temperature changes. The relationships of $\varepsilon_{m s u}$ and $\varepsilon_{m s h}$ with $\varepsilon_{\max }$ can be well described by linear equations, indicating the existence of general patterns

across biomes. And as expected, The LUE models with the seasonal fluctuations of $\varepsilon_{\text {max }}, \varepsilon_{m s u}$ and $\varepsilon_{m s h}$ significantly improved GPP estimation except for needleleaf evergreen forests in mid- and lowlatitude regions. The improvements of both the SL-LUE and TL-LUE models were most significant in summer for tropical and Mediterranean climate regions, while most evident in spring and winter for temperate and boreal climate regions. Even with seasonal parameters, both the LUE models still cannot well capture GPP dynamics in cold season for some PFTs in Mediterranean and tropical regions (e.g., taking into account seasonal variations of the key parameters.

34 Keywords: light use efficiency (LUE) models; seasonal variations of maximum LUE parameters; Capacity of gross primary production; Metropolis-Hasting algorithm; eddy covariance

\section{Introduction}

Terrestrial carbon storage and its variation play a significant role in the global carbon cycle (Gao and Liu, 2008). Gross primary production (GPP) determines the thermal, hydrologic and 
biogeochemical cycles in terrestrial ecosystems (Odum et al., 2009). Quantitative estimation of GPP at various temporal and spatial scales is important for understanding the interactions between ecosystems and climate change (Grace et al., 2007; Cheng et al., 2014). Many approaches were developed to estimate GPP (Monteith, 1972; Farquhar et al., 1980; Baldocchi, 2001; Beer et al., 2007). One of the widely accepted concepts is the light use efficiency (LUE) (Monteith, 1972, 1977), because of both its theoretical basis and practicality (Running et al., 2000; Yuan et al., 2007) and its utility for connecting eddy covariance observations of carbon fluxes (e.g., Thurner et al., 2014; He et al., 2013; Yuan et al., 2014) and remotely sensed data (e.g., Xiao et al., 2005; Yuan et al. 2007; Wu et al., 2010). LUE, defined as the $\mathrm{CO}_{2}$ uptake per unit photons absorbed by vegetation, is straightforward and physiologically based (Field et al., 1994; Haxeltine and Prentice 1996; Medlyn, 1998; Goetz and Prince, 1999). It has been used in many production efficiency models at different spatial and temporal scales (Running et al., 2004; Heinsch et al., 2003; Yuan et al., 2007; Zhao et al., 2010; He et al., 2013). However, even though the eddy covariance (EC) flux data and remotely sensed data are conjunctively introduced into various LUE models, the uncertainties in GPP estimation are still large (Chen et al., 53 2014).

To reduce the GPP uncertainties in LUE models, parameter adjustment (e.g., Chen et al., 2014; Zhou et al., 2015) and structural modification (e.g., He et al., 2013; Zhang et al., 2015) have been developed. The former can compensate for errors derived from the latter (Kanniah et al., 2009; Chen et al., 2010; Bonan et al., 2011; Chen et al., 2014). However, some studies note that parameter adjustment by correcting parameters using flux tower observations or adding control factors still cannot capture the photosynthetic dynamics in spring and fall for forests and shrubs and seasonal GPP change for 60 grasslands (Hashimoto et al., 2013; Chen et al., 2014). Little attention was given to the seasonal and phenological variations of key parameters and variables in carbon assimilation. This issue must be

62 clarified and resolved to reduce the uncertainties in GPP estimates on regional and global scales. 
Therefore, the purpose of this study is to determine the monthly values of LUE parameters

$64\left(\varepsilon_{\max }, \varepsilon_{m s u}\right.$ and $\left.\varepsilon_{m s h}\right)$ and to examine the seasonal response of these parameters for multiple plant 65 functional types (PFTs). The specific objectives of this study are threefold: (1) to investigate seasonal variations of the LUE parameters, (2) to evaluate the response of GPP to seasonal LUE variations, and

67 (3) to determine whether it is possible to estimate GPP for a given PFT for all phases with a single set of LUE parameters.

We hypothesize that incorporating the seasonal variations of LUE parameters can improve GPP estimation and can reasonably capture seasonally photosynthetic dynamics. We used EC measurements to optimize the maximum LUE with monthly-dataset. The selected EC towers represent 18 PFTs across 11 biome types in 4 main climate zones. Then we compared the adjusted estimations with the observations and simulations using default parameters.

\section{2. Materials and methods}

75 2.1. Data used

$76 \quad 2.1 .1$ Eddy covariance data

77 The half-hourly meteorological and carbon fluxes data, acquired from the FLUXNET network 78 (http://fluxnet.ornl.gov/), were used to parameterize and evaluate the one-leaf and two-leaf LUE models. The EC tower sites were selected based on data availability of key variables (Chen et al., 2014).

80 In total, 176 site-years data from 46 sites were selected and all EC measurements were processed in a manner consistent with the FLUXNET project (Baldocchi et al., 2001; 2008). The observations spans

82 the period from January 2000 to December 2010. And each site contains at least two years of data coverage. 92 of the 176 site-years observations were used for parameter optimization (two years for each site). And the remaining data were used for model validation. Detailed information of each site is shown in Fig. 1 and Table 1. 
87 Global inventory modeling and mapping studies (GIMMS) LAI3g dataset (Zhu et al., 2013) were 88 used to drive the two LUE models. This dataset provides 15-day composite LAI values for each pixel where flux towers locate in. The LAI values were extracted referring to Zhou et al., 2015, single-pixel 90 containing the coordinates for a tower was extracted. The resulting LAI time series of each site were further smoothed using the locally adjusted cubic-spline capping (LACC) method (Chen et al., 2006) to 92 remove unrealistically short-term abrupt changes in LAI due to the contamination of the measurements by clouds or the presence of ground snow or ice.

\section{2.2. Model description}

\subsubsection{One-leaf light use efficiency model}

The one-leaf LUE model (SL-LUE) model is based on the radiation conversion efficiency concept of

97 Monteith (1972) and described as follows:

$G P P=\varepsilon_{\max } \times A P A R \times f(V P D) \times g\left(T_{a}\right)$

99 Where $\varepsilon_{\max }$ is the maximum LUE $\left(\mathrm{gC} \mathrm{MJ}^{-1}\right)$ without environment stress, which relates to plant

100 functional type, $A P A R$ is the incident photosynthetically active radiation $(P A R)$ absorbed by the 101 vegetation, $f(V P D)$ and $g\left(T_{a}\right)$ are the scalars of vapor pressure deficit $(V P D)$ and the minimum air 102 temperature $\left(T_{a}\right)$, respectively, both of which range from 0 to 1 to downscale $\varepsilon_{\max }$ of the canopy to the 103 actual LUE value. They are calculated as:

$104 g\left(T_{a}\right)=\left\{\begin{array}{cc}0 & T_{a} \leq T_{\min } \\ \frac{T_{a}-T_{\min }}{T_{\max }-T_{\min }} & T_{\min }<T_{a}<T_{\max } \\ 1 & T_{a} \geq T_{\max }\end{array}\right.$ 
$105 f(V P D)=\left\{\begin{array}{cc}0 & V P D \geq V P D_{\text {max }} \\ \frac{V P D_{\max }-V P D}{V P D_{\max }-V P D_{\text {min }}} & V P D_{\text {min }}<V P D<V P D_{\text {max }} \\ 1 & V P D \leq V P D_{\text {min }}\end{array}\right.$

106 where $V P D_{\max }, V P D_{\min }, T_{\max }, T_{\min }$ are PFT-dependent parameters (Running et al. 2000; Heinsch et 107 al., 2003; Liang et al., 2012; Cescatti, 2012; He et al. 2013) (Table 2).

$108 \quad$ 2.2.2. Two-leaf light use efficiency model

109 The two-leaf LUE model (TL-LUE) is based on the SL-LUE and Dynamic Land Model (DLM, Chen 110 et al., 2014). It calculates GPP by separately calculating the GPP of sunlit and shaded leaves as:

$111 G P P=\left(\varepsilon_{m s u} \times A P A R_{s u}+\varepsilon_{m s h} \times A P A R_{s h}\right) \times f(V P D) \times g\left(T_{a}\right)$

112 where $\varepsilon_{m s u}$ and $\varepsilon_{m s h}$ are the maximum LUE for sunlit and shaded leaves, 113 respectively; $A P A R_{s u}$ and $A P A R_{s h}$ are the $P A R$ absorbed by sunlit and shaded leaves. They are 114 calculated as:

$115 \quad A_{P A R_{s h}}=(1-\alpha) \times\left[\left(P A R_{d i f}-P A R_{d i f, u}\right) / L A I+C\right] \times L A I_{s h}$

116

$A P A R_{s u}=(1-\alpha) \times\left(P A R_{d i r} \times \cos (\beta) / \cos (\theta)+\left(P A R_{d i f}-P A R_{d i f, u}\right) / L A I+C\right) \times L A I_{s u}$

117 where $\alpha$ is the canopy albedo related to vegetation types (Table 2), PAR dif and $P A R_{d i r}$ are the 118 diffuse and direct components of incoming PAR, respectively. They are calculated using Eq. (7). $119 P A R_{d i f, u}$ is the diffuse $P A R$ under the canopy and calculated following Chen et al., (1999); $120\left(P A R_{d i f}-P A R_{d i f, u}\right) / L A I$ represents the diffuse $P A R$ on per unit leaf area within the canopy; $C$ 121 quantifies the contribution of multiple scattering of the total $P A R$ to the diffuse irradiance per unit 122 leaf area within the canopy (Norman, 1982); $\beta$ is the mean leaf-sun angle and set as $60^{\circ}$ for a 123 canopy with spherical leaf angle distribution (Chen et al., 1999); and $\theta$ is the solar zenith angle. 
125 parameters ( $f$ and $g$ in Eq. (7)) calibrated using half-hourly diffuse and total incoming radiation 126 data measured at different PFTs.

$127 \quad P A R_{d i f}=\frac{1}{\exp (f+g \times R)} \times P A R$

$128 P A R_{d i r}=P A R-P A R_{d i f}$

129 where $R$ is the sky clearness index and equals $\left(P A R / 0.5 S_{0} \cos \theta\right) ; S_{0}$ is the solar constant (1367

$130 \mathrm{~W} \mathrm{~m} \mathrm{~m}^{-2}$ ). A constant 0.5 is used to convert incoming solar radiation into PAR (Weiss and Norman, 131 1985; Tsubo and Walker, 2005; Bosch et al., 2009).

132 The $L A I_{s u}$ and $L A I_{s h}$ are the $L A I$ of sunlit and shaded leaves. They are computed as (Chen et 133 al., 1999; He et al., 2013):

$134 L A I_{s u}=2 \times \cos \theta \times(1-\exp (-0.5 \times \Omega \times L A I / \cos \theta))$

$135 L A I_{s h}=\max \left(0, L A I-L A I_{s u}\right)$

136 where $\theta$ is the solar zenith angle; $L A I$ is the leaf area index; $\Omega$ represents the vegetation 137 clumping index according to Table 2.

138 2.3. Parameterization procedure

139 The LUE parameters $\left(\varepsilon_{\max }, \varepsilon_{m s u}\right.$ and $\left.\varepsilon_{m s h}\right)$ were calibrated using the Bayesian method, which is 140 based on Bayes' theorem combined with Markov Chain Monte Carlo (MCMC) estimator (Braswell et 141 al., 2005). In this approach, the data assimilation scheme is based on Metropolis-Hasting (MH) 142 algorithm (Chib et al., 1995). The lower and upper bounds of $\varepsilon_{\max }, \varepsilon_{m s u}$ and $\varepsilon_{m s h}$ were determined from 143 the range of these parameters used in LUE models (He et al., 2013; Yuan et al., 2014; Chen et al., 2014; 144 Zhou et al., 2015). The procedure begins by the prior probability distribution as the uncertainty about 145 parameter values. Then observations (e.g., GPP) were used to yield an updated posterior distribution of 
the parameters. Next the MH algorithm generated a representative sample of parameter vectors from

147 the posterior distribution by multiplying the prior with its corresponding data likelihood function,

148 which usually assumes that the model error (the difference between the estimated and observed values)

149 is independent and normally distributed with zero-mean (Van et al. 2005; Svensson et al. 2008).

150 Logarithmic likelihood function is used to improve numerical stability and make $L$ easier to work 151 with:

$152 \log L=\sum_{i=1}^{n}\left[-0.5\left(\frac{\mathrm{obs}_{i}-\operatorname{sim}_{i}}{\delta_{i}}\right) 2-0.5 \log (2 \pi)-\log \left(s t d_{i}\right)\right]$

153 where $\mathrm{n}$ is the number of data points; $o b s_{i}$ is the observed GPP for measurement $i(i=1,2, \ldots, \mathrm{n}), \quad \operatorname{sim}_{i}$

154 is the model estimation with the LUE parameters, and $s t d_{i}$ is the standard deviation of the model 155 error.

156 The prior distributions of the calibration parameters are chosen as normal distribution centered on 157 values reported in the literature (Table 2) and non-correlated. The first step of MCMC is to run an 158 initial simulation with parameter values from an arbitrary point $\varepsilon^{(0)}$, and to calculate the total data 159 likelihood of that point with Eq. (11). The second step is to generate a candidate point $\varepsilon^{(\text {new })}$ according 160 to a proposal density $P\left(\varepsilon^{(\text {new })} \mid \varepsilon^{(k-1)}\right)$. The point $\varepsilon^{(\text {new })}$ is accepted or rejected against the Metropolis 161 criterion. Thus, a chain of accepted parameter values and corresponding simulation results are 162 generated. We ran five parallel MCMC chains with 50,000 iterations each, evaluated the chains for 163 convergence, and thinned the chains (every 30th iteration) when appropriate to reduce within-chain 164 autocorrelation, thereby producing an independent sample of 5000 values for each parameter from the 165 joint posterior distribution. The parameters of the LUE models were fitted to carbon exchange data. 166 And the posterior mean and 95\% confidence intervals (CIs: i.e., 2.5th and 97.5th percentiles) can be 167 obtained from values of each parameter for each month. 
We performed the following simulations to document seasonal variations of maximum LUE parameters applied to the one-leaf and two-leaf LUE algorithm:

LUE $_{\text {def }}$ : A simulation with the one-leaf algorithm and the default biome-parameters supplied by

BPLUT (Table 2) (Zhao et al., 2010);

SL-LUE: A simulation with the one-leaf algorithm (Eq. (1)) and optimized monthly biome-

parameters $\left(\varepsilon_{\max }\right)$, to investigate error introduced by the fixed maximum LUE values;

TL-LUE: A simulations with the two-leaf algorithm (Eq. (4)) and optimized monthly biomesunlit and shaded leaves.

\subsection{Evaluation of model performance}

179

The degree of seasonal variations of maximum LUE parameters were quantified by coefficient of variation $(C V)$ (Bonett et al., 2006), which is defined as:

$181 \quad C V=\sqrt{\sum_{i=1}^{n}\left(\varepsilon_{\max _{i}}-\bar{\varepsilon}_{\max }\right)^{2} /(n-1)} / \bar{\varepsilon}_{\max } \times 100 \%$

The performance of model estimations was quantified by statistical analysis based on the halfhourly GPP for each model-data pair. Estimation-Observation mismatch was evaluated using the bias, coefficient of determination $\left(R^{2}\right)$ and the root mean square error ( $R M S E$ ) (Willmott et al., 1985, 2005).

185 The accuracy of model performance was characterized by Taylor diagram and Taylor skill ( $S$ ) (Taylor et al., 2001). Every point in the Taylor diagram indicates the linear correlation coefficient $(R)$, the normalized standard deviations and the root-mean-square ( $R M S)$ difference of the two patterns. A single point in $S$ is a single-value summary of a Taylor diagram, which is used to indicate perfect agreement with observations. Each point for any arbitrary data group (Taylor et al., 2001; Schwalm et 
$S=2(1+R) /\left(\sigma_{\text {norm }}+1 / \sigma_{\text {norm }}\right)^{2}$

\section{3. Results}

193 3.1. Posterior distribution of the LUE model parameters

194 We optimized the key parameters $\left(\varepsilon_{\max }, \varepsilon_{m s u}\right.$ and $\left.\varepsilon_{m s h}\right)$ of the SL-LUE and TL-LUE models. Fig. 2 195 and Table 3 show plots and seasonal coefficient of variation $(C V)$ of the posterior parameter 196 distributions (PDFs) corresponding to the means after calibration with the different monthly dataset 197 procedures. Such representation makes it possible to visualize monthly differences in the optimized 198 parameters for different PDFs, while the shape of the plot reveals the dispersion and symmetry of the 199 marginal distributions (Lehuger et al. 2009). For all PFTs, optimized $\varepsilon_{\max }$ values were always 200 between $\varepsilon_{m s u}$ and $\varepsilon_{m s h}$ and the values of $\varepsilon_{m s u}$ were the lowest for all months. The main 201 photosynthetic parameters $\left(\varepsilon_{\max }, \varepsilon_{m s u}\right.$ and $\varepsilon_{m s h}$ ) varied substantially among the different plant 202 functional types and were updated well by the MCMC procedure for most PFTs in all seasons, as 203 demonstrated by seasonal variabilities and large $C V$ for these parameters (Fig. 2; Table 3). The 204 averaged $C V$ ranged from $12.43 \%$ in summer to $34.28 \%$ in spring for $\varepsilon_{\max }$, from $33.38 \%$ in summer to $51.50 \%$ in fall for $\varepsilon_{m s u}$, and from $21.01 \%$ in summer to $35.97 \%$ in spring for $\varepsilon_{m s h}$, respectively. However, this was not the case for needleleaf evergreen forest (NEF) in temperate and Mediterranean regions. That is, the posterior estimations of maximum LUE parameters were held relatively constant 208 for different seasons with small $C V$ throughout the seasons (Fig. 2b). In addition, we found that the 209 posterior means of these parameters showed similar variation trends overall. For example, the average 210 values of them for most PFTs showed a monopeak curve across four seasons with the peak appeared in 211 winter for Tropical-BEF and Mediterranean-BEF or in summer for other PFTs, while showed a 212 multiple extremums curve for $\mathrm{C} 3$ grass and $\mathrm{C} 3 / \mathrm{C} 4$ grass. 
3.2. Model-data agreement relative to climatic season

214 We simulated seasonal GPP using the one-leaf and two-leaf LUE models with default annual 215 parameters $\left(L_{U E} E_{\text {def }}\right)$ and optimized monthly parameters.The simulation results were compared with 216 observed GPP values using Taylor skill $(S)$ to explore the model's feedback to various weather 217 conditions in different seasons (Fig. 3). The site-level model-data agreement of SL-LUE and TL-LUE 218 exhibited an obvious low degree of scatter for all seasons, while LUE $_{\text {def }}$ had a large range of Taylor 219 skill (ranged from zero to unity) especially in cold seasons. SL-LUE and TL-LUE produced higher $\mathrm{R}^{2}$ 220 and lower RMSE values than LUE $_{\text {lef }}$ for all seasons. The variations of GPP explained by SL-LUE and 221 TL-LUE were $64.1 \%$ and $68.6 \%$, with averaged $\mathrm{R}^{2}$ values increased by $2.3 \%$ and $6.8 \%$ than LUE $_{\text {def. }}$. 222 And the corresponding averaged RMSE values reduced by 0.52 and $0.81 \mu \mathrm{mol} \cdot \mathrm{m}^{-2} \cdot \mathrm{s}^{-1}$, respectively. 223 Although LUE $_{\text {def }}$ had small biases in spring and fall (Table 4), its standard deviation was much greater 224 225 than the average bias of SL-LUE and TL-LUE, Thus, the small biases of LUE $E_{\text {def }}$ were most likely caused by terms with opposite signs cancelling each other. In contrast, the biases of SL-LUE and TLLUE both had an obviously lower degree of scatter (mostly concentrated in $0.2 \mu \mathrm{mol} \cdot \mathrm{m}^{-2} \cdot \mathrm{s}^{-1}$ ) in all seasons. These results imply that incorporating the seasonal fluctuations of LUE could improve the robustness of GPP simulations and reduce the uncertainties for both the one-leaf and two-leaf LUE models.

In addition, the improvement of the SL-LUE and TL-LUE models than the LUE def model was most significant in spring, especially in April, with the RMSE decreased by 0.89 and $1.13 \mu \mathrm{mol} \cdot \mathrm{m}^{-2} \cdot \mathrm{s}^{-1}$, respectively (Table 4). It is noteworthy that the $\mathrm{LUE}_{\text {def }}$ model tends to seriously underestimate or overestimate GPP, especially in summer where the bias of $-1.19( \pm 1.53) \mu \mathrm{mol} \cdot \mathrm{m}^{-2} \cdot \mathrm{s}^{-1}$, while the bias in the SL-LUE and TL-LUE models in summer was reduced $\left(0.40\right.$ and $0.68 \mu \mathrm{mol} \cdot \mathrm{m}^{-2} \cdot \mathrm{s}^{-1}$, respectively). These analyses suggest again that it would be important to incorporate the physiological changes in the 236 photosynthetic parameters for the LUE models. 
The differences in modeling efficiency among the LUE $_{\text {def }}$, SL-LUE and TL-LUE models (both across-PFT and across-model) were then quantified using Taylor diagrams (Fig. 5). The average modeldata agreement $\left(\sigma_{\text {norm }}\right.$ ) values for $\mathrm{LUE}_{\text {def }}$ model ranged from 0.23 to 1.97 , with R-values of 0.54-0.90.

The SL-LUE and TL-LUE models had the average values of $\sigma_{\text {norm }} 0.91( \pm 0.04)$ and $0.91( \pm 0.02)$, in R of $0.80( \pm 0.07)$ and $0.82( \pm 0.08)$, respectively. However, it is not the case for some PFTs. For instance, the Mediterranean-NEF and temperate-NEF (number 11 and 15 in Fig. 5a-5c, number 6 and 8 in Fig.

5d), the averaged $\sigma_{\text {norm }}$ of them only increased by $0.02( \pm 0.01)$ (see also Fig. 2 and Table 3). Fig. 6

further quantified the improvement of incorporating the seasonal variations of LUE values. The

increase of $\mathrm{R}^{2}\left(\Delta \mathrm{R}^{2}\right)$ and the decrease of RMSE ( $\triangle \mathrm{RMSE}, \mathrm{gC} \cdot \mathrm{m}^{-2} \cdot$ season $^{-1}$ ) were most significant in summer and fall (red and blue bar in Fig. 6) for biomes in tropical and Mediterranean climate regions, while most obvious in spring and winter (black and magenta bar in Fig. 6) for biomes in temperate and boreal climate regions. Similar results can also be seen in Fig. 7 (orange box), which comparing the 250 simulations and observations of monthly composite diurnal variations for each PFT. The simulated GPP overall captured the observed diurnal variations within or near the margin of \pm 1 standard deviation for most PFTs. The performance of the LUE ${ }_{\text {def }}$ model varied with seasons. For instance, it underestimated GPP in summer and overestimated GPP in cold season for most PFTs and it overestimated GPP for Mediterranean-BEF and C3 grass in Arctic in summer (Fig. 7-b2 and Fig. 7-c3). The modeled GPP by the SL-LUE and TL-LUE models in contrast were consistent with measurements for most PFTs for all seasons $\left(R^{2}=0.63-0.98\right.$ and $0.73-0.99$, and RMSE $=0.32-4.88$ and $0.22-4.45 \mu \mathrm{mol} \cdot \mathrm{m}^{-2} \cdot \mathrm{s}^{-1}$, respectively). In the example shown, the LUE model using the default parameters already performs very well for Mediterranean-NEF (Fig. 7-b3) and Temperate-NEF (Fig. 7-b4), so little improvement is needed. However, though incorporating the seasonal fluctuations of the maximum LUE parameter, both 
$261 \mathrm{C}_{4}$ grass, similar to the results reported by Chen et al., 2014.

\section{4. Discussion}

263 4.1. Seasonal variations of the LUE model parameters

264 The optimized $\varepsilon_{\max }$ values were in between the values of $\varepsilon_{m s u}$ and $\varepsilon_{m s h}$ for all PFTs. The $\varepsilon_{m s h}$ values 265 were larger than $\varepsilon_{m s u}$ and $\varepsilon_{\max }$ because the shaded leaves are only exposed to diffuse radiation, which 266 enters a canopy from all directions and distributes more evenly than direct radiation within the canopy 267 (Sinclair et al., 1993, Hammer\&Wright, 1994). The intensity of light absorbed by shaded leaves is 268 normally lower than light saturation point. Therefore, they have higher light use efficiency than the 269 sunlit leaves. The value of $\varepsilon_{m s h}$ is about four times as much as that of $\varepsilon_{\text {max }}$, while the value of $\varepsilon_{m s u}$ 270 is about $15 \%$ to $70 \%$ lower than the value of $\varepsilon_{\max }$ (Table 3), both larger than that for 6 vegetation types 271 reported by He et al. (2013), in which the value of $\varepsilon_{m s h}$ is about two times as much as that of $\varepsilon_{\max }$ 272 and the value of $\varepsilon_{m s u}$ is about $45 \%$ to $59 \%$ lower than the value of $\varepsilon_{\max }$. This can be explained by the 273 fact that 18 PFTs used in this study distributed across Europe, America, Asia and Africa while He et al. 274 (2013) only used 6 typical sites in China.

275 Houborg et al. $(2009 ; 2011)$ demonstrated the importance of allowing the maximum LUE to vary 276 seasonally, responding realistically to changes in leaf biochemistry as well as short-term variations in 277 environmental conditions. In this study, For Temperate-NEF and Mediterranean-NEF, the maximum 278 LUE parameters almost keep constant throughout the four seasons. It may be explained by the fact that 279 coniferous forests are noted for the ability to fix carbon throughout the year at the expense of low 280 physiological activity and slow growth rates (Monk, 1966; Chapin, 1980; Monk \& Day, 1985; 281 Baldocchi et al., 2010), thus the LUE parameters failed to show obvious seasonality (Huang et al., 282 2014). For other PFTs, the posterior means of $\varepsilon_{\max }, \varepsilon_{m s u}$ and $\varepsilon_{m s h}$ were observed to vary significantly 
over the seasons, especially in mid- and high-latitude areas (Fig. 2; Table 3). Seasonal variability of 284 these parameters has been shown to occur in the deciduous forests (Muramatsu et al., 2014; Biudes et 285 al., 2014), coniferous forests and mixed forests (Huang et al., 2014), shrubs (Stagakis et al., 2014; 286 Huang et al., 2014), and grassland (Chen et al., 2010; Huang et al., 2014). Canopy structure is a key 287 factor influencing light interception by a forest stand with a given LAI (Teh et al., 2000) and may 288 influence branching strategies that optimize light capture (Whitney, 1976; Kempf \& Pickett, 1981; 289 Brantley \& Young, 2009). Large seasonal variations in maximum LUE parameters could also be 290 explained by changes in ambient temperatures (Wilson et al., 2000; Medlyn et al. 2002; Xu and 291 Baldocchi 2014; Zhu et al., 2011). Similar results were obtained in this study. The $\mathrm{R}^{2}$ between the 292 maximum LUE parameters and LAI ranged from 0.32 to 0.84 . The corresponding $\mathrm{R}^{2}$ values between 293 the maximum LUE parameters and ambient temperature ranged from 0.11 to 0.40 (Fig. 8).

294 The posterior of $\varepsilon_{\max }, \varepsilon_{m s u}$ and $\varepsilon_{m s h}$ had lower $C V$ value in summer compared with other seasons 295 and $\varepsilon_{m s u}$ had relatively higher $C V$ compared with $\varepsilon_{\max }$ and $\varepsilon_{m s h}$ (Table 3). Evidence has showed that there were no pronounced differences in LUE values from June to September (summer and early fall) and the 297 seasonal variation in LUE (coefficient of variation) was lower on cloudy days $\left(\varepsilon_{m s h}\right)$ than on partly cloudy or sunny days $\left(\varepsilon_{m s u}\right)$ (Chen et al., 2010). In addition, the three parameters mostly have similar variations trends and mostly showed a monopeak or single valley curve across four seasons, with peak 300 or valley values during the mid-growing season (Fig. 2). To understand further how the parameters 301 correlated, we consider the 2-D representation in Fig. 8. The regression analysis shows that both $302 \varepsilon_{m s u}$ and $\varepsilon_{m s h}$ increased linearly with $\varepsilon_{\max }$, with an increase as much as by a half and three times, 303 respectively. Similar findings were also reported by Zhou et al. (2015). This result provides another 304 feasible constraint condition to estimating the maximum LUE values of sunlit and shaded leaves with 305 an unique determination solution by taking the relationship here as a sine qua non. Further validations 
were needed with more flux sites.

\subsection{Responses of GPP to seasonal variations in LUE parameters}

Imposing a seasonal variability of the maximum LUE significantly improved the accuracy of carbon flux estimates in all seasons for both the one-leaf and two-leaf LUE models. The comparison of biases and RMSE indicates that the improvement is more significant in spring and fall seasons (Fig 4 and Table 4), which is consistent with the seasonal fluctuations ( $C V$ ) of the maximum LUE in Table 3 , with the highest $C V$ of $34.28 \%$ for $\varepsilon_{\max }$ in spring, $51.50 \%$ for $\varepsilon_{m s u}$ in fall, and $35.97 \%$ for $\varepsilon_{m s h}$ in spring, respectively. For a given climate region, the outperformance of both the one-leaf and two-leaf models incorporating the seasonal variations of LUE parameter were most significant in summer in tropical and Mediterranean climate regions, while most obvious in spring and winter in temperate and boreal climate regions (Fig. 6 and Fig. 7). These results probably resulted from the determination mode of the maximum LUE in previous studies, which was parameterized with observations in the growing peak season (e.g., Potter et al., 1993; Prince and Goward, 1995; Landsberg and Waring, 1981; Running et al., 2000; Xiao et al., 2004; Yuan et al., 2007; He et al., 2013). For example, the combination of warm-season datasets had a comparatively larger number of observations in temperate and boreal climate regions, and subsequently gained more weight in the likelihood function when using multidataset to parameterize the maximum LUE parameters in the optimized process. And subsequently using monthly-dataset to parameterize the maximum LUE parameters would have a pronounced effect on GPP simulation in cold seasons. However, whether or not to incorporate the seasonal variations of the maximum LUE parameters, both the one-leaf and two-leaf LUE models performed similarly for needleleaf evergreen forests in temperate and Mediterranean regions. Therefore, in order to reduce the number of parameters, previous investigators used fixed values of $\varepsilon_{\max }, \varepsilon_{m s u}$ and $\varepsilon_{m s h}$ for these PFTs (Potter et al., 1993; Yuan et al., 2007; He et al., 2013; Chen et al., 2014). We thought it was acceptable because the CV of them was relatively lower (Table 3) and the simulated GPP showed a little 
4.3. Recommendations for long-term and large-scale applications

The study has two major implications for modeling long term carbon cycle. First, it seems to be more reasonable to take the seasonal variations of these three main photosynthetic parameters into account for long-term modeling applications for most PFTs. In contrast, the low variations of posterior distributions of the maximum LUE parameters for NEF in mid- and low-latitude climate areas in all seasons and for all other PFTs in the temperate and boreal regions in summer, which indicated that these parameters could be constant for modeling purposes.

In addition to LAI and ambient temperature, the variations of $\varepsilon_{\max }, \varepsilon_{m s u}$ and $\varepsilon_{m s h}$ across different

PFTs might also be caused by several other factors, including forest age, nitrogen content of leaves, and fraction of diffuse radiation. These factors have not been included yet in the SL-LUE and TL-LUE models, suggesting the necessity of further improving their parameterization for a better simulation of GPP. The inclusion of the changes in LUE with the factors mentioned above will further improve the ability of LUE models to simulate GPP. Thus, a function of them should be used to describe the seasonal variations of the photosynthetic capacity parameters. Secondly, our study indicated that parameters estimated by the Bayesian method based on half-hourly gas-exchange data have a strong linear relationship for most PFTs. This relationship could be used for estimating maximum LUE of sunlit and shaded leaves with unique determination solution by taking the relationship here as a constraint condition.

As the canopy-scale $\mathrm{CO}_{2}$ fluxes are the integral representation of the individual leaf-scale photosynthesis process, the eddy covariance measurements can be used to obtain the biological parameters for the terrestrial ecosystem models. However, there is still much to learn about the differences in parameters determined by data at different scales (e.g., leaf-scale and canopy-scale) using more flux data, and the mechanistic correlation between them. 


\section{Conclusions}

By comparing the performances of the LUE models with and without consideration of seasonal parameterization adjustment for 18 PFTs, the main findings can be as follows:

(1) Consideration of the seasonal variations of the maximum LUE parameters $\left(\varepsilon_{\max }, \varepsilon_{m s u}\right.$ and $\varepsilon_{m s h}$ ) was more satisfactory in GPP simulation than with default annual parameters (especially in spring and winter). For most PFTs, namely in temperate and boreal climate regions in the cold seasons and in the tropical and Mediterranean climate regions in the warm seasons, the seasonal fluctuations of 361 photosynthetic parameters should be incorporated in estimating GPP; while for the needleleaf 362 evergreen forests in mid- and low- latitude, it is acceptable to estimate GPP for all seasons with annual parameters.

(2) Even with seasonal parameters, both the one-leaf and two-leaf LUE models cannot correctly capture the seasonal GPP dynamics for some PFTs in Mediterranean and tropical regions (e.g.,

Tropical-BEF, C3-C4 grass). Further improvement in the LUE models is required based on more and better cold-season observations and incorporate the seasonal variations of the other key parameters and variables for these PFTs.

\section{Acknowledgments}

This work was supported by the research grant (No. 2013BAC03B04) of National Key

Technology Support Program, the research grants (No. O88RA901YA and No. O8R8A085YA) by the

State Key Laboratory of Resources and Environment Information System and the research grants (No. 41271116, 31500402 and 31500402) funded by the National Science Foundation of China. We thank the agencies that supported the operations at the flux towers used here, which are part of FLUXNET.

\section{References}

376 Archibald, S. A., Kirton, A., van der Merwe M. R., Scholes, R. J., Williams, C. A., Hanan, N., 2009. 
Drivers of inter-annual variability in Net Ecosystem Exchange in a semi-arid savanna ecosystem, South Africa. Biogeosciences. 6, 251-266, http://dx.doi.org/10.5194/bg-6-251-2009.

Aurela, M., Laurila, T., Tuovinen, J. P., 2001. Seasonal CO2 balance of a subarctic mire. Journal of Geophysical Research Atmospheres. 106, 1623-1637, http://dx.doi.org/10.1029/2000JD900481.

Bakwin, P. S., Davis, K. J., Yi, C., Wofsy, S. C., Munger, J. W., Haszpra, L., Barcza, Z., 2004. Regional

Baldocchi, D. D., Ma, S., Rambal, S., Misson, L., Ourcival, J. M., Limousin, J. M., Pereira, J., Papale, D., 2010. On the differential advantages of evergreenness and deciduousness in mediterranean oak woodlands: a flux perspective. Ecological Applications A Publication of the Ecological Society of America. 20, 1583-1597, http://dx.doi.org/10.1890/08-2047.1.

Baldocchi, D., 2008. Breathing of the terrestrial biosphere: lessons learned from a global network of carbon dioxide flux measurement systems. Australian Journal of Botany. 56, 1-26, http://dx.doi.org/10.1071/BT07151.

Baldocchi, D., Falge, E., Gu, L., Olson, R., Hollinger, D., Running, S., Anthoni, P., Bernhofer, C., Davis, K., Evans, R., Fuentes, J., Goldstein, A., Katul, G., Law, B., Lee, X., Malhi, Y., Meyers, T., Munger, W., Oechel, W., U K. T. P., Pilegaard, K., Schmid, H. P., Valentini, R., Verma, S., Vesala, T., Wilson, K., Wofsy, S., 2001. Fluxnet: a new tool to study the temporal and spatial variability of ecosystem-scale carbon dioxide, water vapor, and energy flux densities. Bulletin of the American Meteorological Society. 82, 2415-2434, http://dx.doi.org/10.1175/1520-0477(2001)0822.3.CO;2.

Barr, A. G., Black, T. A., Hogg, E. H., Griffis, T. J., Morgenstern, K., Kljun, N., Theede. A., Nesic, Z., 2007. Climatic controls on the carbon and water balances of a boreal aspen forest, 1994-2003. Global Change Biology. 13, 561-576, http://dx.doi.org/10.1111/j.1365-2486.2006.01220.x.

Barr, A. G., Richardson, A. D., Hollinger, D. Y., Papale, D., Arain, M. A., Black, T. A., Bohrer, G., 401 Dragoni, D., Fischer, M. L., Gu, L., Law, B. E., Margolis, H. A., McCaughey, J. H., Munger, J. W., 
Oechel, W., Schaeffer, K., 2013. Use of change-point detection for friction-velocity threshold evaluation in eddy-covariance studies. Agricultural \& Forest Meteorology. 171-172, 31-45, http://dx.doi.org/10.1016/j.agrformet.2012.11.023.

Beer, C., Reichstein, M., Ciais, P., Farquhar, G. D., Papale, D., 2007. Mean annual gpp of europe derived from its water balance. Geophysical Research Letters. 34, 306-316, http://dx.doi.org/10.1029/2006GL029006.

Berbigier, P., Bonnefond, J. M., Mellmann, P., 2001. $\mathrm{CO}_{2}$, and water vapour fluxes for 2 years above euroflux forest site. Agricultural \& Forest Meteorology. 108, 183-197, http://dx.doi.org/10.1016/S0168-1923(01)00240-4.

Bernier, P. Y., Bartlett, P., Black, T. A., Barr, A., Kljun, N., Mccaughey, J. H., 2006. Drought constraints on transpiration and canopy conductance in mature aspen and jack pine stands. Agricultural \& Forest Meteorology. 140, 64-78, http://dx.doi.org/10.1016/j.agrformet.2006.03.019.

Biudes, M. S., Souza, Maí, Caldas, S., Machado, N. G., Hugo, D. M. D. V., Vourlitis, G. L., 2014. Modelling gross primary production of a tropical semi-deciduous forest in the southern amazon basin. International Journal of Remote Sensing. 35, 1540-1562, http://dx.doi.org/10.1080/01431161.2013.878059.

Boland, J., Ridley, B., 2008. Models of Diffuse Solar Fraction. Modeling Solar Radiation at the Earth's Surface, pp.193-219.

Boland, J., Scott, L., Luther, M., 2001. Modelling the diffuse fraction of global solar radiation on a horizontal surface. Environmetrics. 12,103-116, http://dx.doi.org/10.1002/1099095X(200103)12:2<103::AID-ENV447>3.0.CO;2-2.

Bonan, G. B., Lawrence, P. J., Oleson, K. W., Levis, S., Jung, M., Reichstein, M., Lawrence, D. M., Swenson, S. C., 2011. Improving canopy processes in the community land model version 4 (clm4) using global flux fields empirically inferred from fluxnet data. Journal of Geophysical Research Biogeosciences. 116, 96-101, http://dx.doi.org/10.1029/2010JG001593. 
Bonan, G. B., Levis, S., Kergoat, L., Oleson, K. W., 2002. Landscapes as patches of plant functional types: an integrating concept for climate and ecosystem models. Global Biogeochemical Cycles. 16, 5-1-5-23, http://dx.doi.org/10.1029/2000GB001360.

Bonett, D. G., 2006. Confidence interval for a coefficient of quartile variation. Computational Statistics \& Data Analysis. 50, 2953-2957, http://dx.doi.org/10.1016/j.csda.2005.05.007.

Bosch, J. L., López, G., Batlles, F. J., 2009. Global and direct photosynthetically active radiation parameterizations for clear-sky conditions. Agricultural \& Forest Meteorology, 149(1), 146-158.

Braswell, B.H., Sacks, W. J., Linder, E., Schimel, D. S., 2005. Estimating diurnal to annual ecosystem parameters by synthesis of a carbon flux model with eddy covariance net ecosystem exchange observations. Global Change Biol. 11, 335-355, http://dx.doi.org/10.1111/j.1365-2486.2005.00897.x.

Brümmer, C., Black, T. A., Jassal, R. S., Grant, N. J., Spittlehouse, D. L., Chen, B., Nesic, Z., Amiro. B. D., Arain, M. A.,Barr, A. G., Bourque, C. P. A., Coursolle, C., Dunn, A. L., Flanagan, L. B., Humphreys, E. R., Lafleur, P. M., Margolis, H. A., McCaughey, J. H., Wofsy, S. C., 2012. How climate and vegetation type influence evapotranspiration and water use efficiency in canadian forest, peatland and grassland ecosystems. Agricultural \& Forest Meteorology. 153, 14-30, http://dx.doi.org/10.1016/j.agrformet.2011.04.008.

Carlin, B. P., \& Chib, S., 1995. Bayesian model choice via markov chain monte carlo. Journal of the Royal Statistical Society, 57(3), http://dx.doi.org/10.2307/2346151.

Cescatti, A., Marcolla, B., Vannan, S. K. S., Pan, J. Y., Román, M. O., Yang, X., Ciais, P., Cook, R. B., Law, B. E., Matteucci, G., Migliavacca, M., Moors, E., Richardson, A. D., Seufert, G., Schaaf, C. B., 451 2012. Intercomparison of modis albedo retrievals and in situ measurements across the global fluxnet network. Remote Sensing of Environment. 121, 323-334, 
453 Chapin, F.S., III, 1980. The mineral nutrition of wild plants. Annual Review of Ecology and $454 \quad$ Systematics. 11, 233-260, http://dx.doi.org/10.1146/annurev.es.11.110180.001313.

455 Chen, H., Dickinson, R. E., Dai, Y., Zhou, L., 2010. Sensitivity of simulated terrestrial carbon 456 assimilation and canopy transpiration to different stomatal conductance and carbon assimilation 457 schemes. Climate Dynamics. 36, 1037-1054, http://dx.doi.org/10.1007/s00382-010-0741-2.

458 Chen, J. M., Liu, J., Cihlar, J., Goulden, M. L., 1999. Daily canopy photosynthesis model through 459 temporal and spatial scaling for remote sensing applications. Ecological Modelling. 124, 99-119, 460 http://dx.doi.org/10.1016/S0304-3800(99)00156-8.

461 Chen, J., Zhang, H., Liu, Z., Che, M., Chen, B., 2014. Evaluating Parameter Adjustment in the MODIS 462 Gross Primary Production Algorithm Based on Eddy Covariance Tower Measurements. Remote 463 Sensing. 6, 3321-3348, http://dx.doi.org/10.3390/rs6043321.

464 Chen, M., Deng, F., Chen, M., 2006. Locally adjusted cubic-spline capping for reconstructing seasonal 465 trajectories of a satellite-derived surface parameter. IEEE Transactions on Geoscience \& Remote 466 Sensing, 44(8), 2230-2238, http://dx.doi.org/10.1109/TGRS.2006.872089.

467 Cheng, Y. B., Zhang, Q., Lyapustin, A. I., Wang, Y., Middleton, E. M., 2014. Impacts of light use 468 efficiency and fpar parameterization on gross primary production modeling. Agricultural \& Forest 469 Meteorology. 189-190, 187-197, http://dx.doi.org/10.1016/j.agrformet.2014.01.006.

470 Ciais, P., Bombelli, A., Williams, M., Piao, S. L., Chave, J., Ryan, C. M., Henry, M., Brender, P., 471 Valentini, R., 2011. The carbon balance of Africa: synthesis of recent research studies. Philosophical 472 Transactions of the Royal Society A: Mathematical, Physical and Engineering Sciences. 369, 2038$473 \quad$ 2057, http://dx.doi.org/10.1098/rsta.2010.0328.

474 Coursolle, C., Margolis, H. A., Giasson, M. A., Bernier, P. Y., Amiro, B. D., Arain, M. A., Barr, A. G., 475 Goulden, M. L., McCaughey, J. H., Chen, J. M., Dunn, A. L., Grant, R. F., Lafleur, P. M., 2012. 476 Influence of stand age on the magnitude and seasonality of carbon fluxes in canadian forests. 
Cramer, W., Shugart, H.H., Noble, I.R., Woodward, F.I., Bugmann, H., Bondeau, A., Foley, J.A.,

479

480
Gardner, R.H., Lauenroth, B., Pitelka, L.F., Sala, O., Sutherst, R.W., 1999b. Ecosystem composition and structure. In: Walker, B.H., Steffen, W.L., Canadell, J., Ingram, J.S.I. (Eds.), The Terrestrial Biosphere and Global Change: Implications for Natural and Managed Ecosystems, vol. 4. Cambridge University Press. IGBP Book Series, Cambridge, pp. 190-228.

Eugster, W., Rouse, W. R., Pielke Sr, R. A., Mcfadden, J. P., Baldocchi, D. D., Kittel, T. G., III F. S. C., Liston, G. E., Vidale, P. L., Vaganov, E., Chambers, S., 2000. Land-atmosphere energy exchange in Arctic tundra and boreal forest: available data and feedbacks to climate. Global change biology. 6 , 84-115, http://dx.doi.org/10.1046/j.1365-2486.2000.06015.x.

Farquhar, G. D., Caemmerer, S. V., Berry, J. A., 1980. A biochemical model of photosynthetic CO2 assimilation in leaves of c3 species. Planta. 149, 78-90, http://dx.doi.org/10.1007/BF00386231.

Field, C. B., Gamon, J. A., Penuelas, J., 1994. Remote sensing of photosynthesis. In: Schulze, E.D., Caldwell, M.M. (Eds.), Ecophysiology of Photosynthesis. Springer, New York, pp. 511-527.

Fisher, J. B., Malhi, Y., Bonal, D., Da Rocha, H. R., De Araujo, A. C., Gamo, M., Goulden, M. L., Hirano, T., Huete, A. R., Kondo, H., Kumagai, T., Loescher, H. W., Miller, S., Nobre, A. D., Nouvellon, Y., Oberbauer, S. F., Panuthai, S., Roupsard, O., Saleska, S., Tanaka, K., Tanaka, N., Tu, K. P., Randow, C. V., 2009. The land-atmosphere water flux in the tropics. Global Change Biology. 15, 2694-2714, http://dx.doi.org/10.1111/j.1365-2486.2008.01813.x.

Fisher, J. B., Tu, K. P., Baldocchi, D. D., 2008. Global estimates of the land-atmosphere water flux based on monthly avhrr and islscp-ii data, validated at 16 fluxnet sites. Remote Sensing of Environment. 112, 901-919, http://dx.doi.org/10.1016/j.rse.2007.06.025.

Gao, Z. Q., Liu, J. Y., 2008. Simulation study of china’s net primary production. Chinese Science Bulletin. 53, 434-443, http://dx.doi.org/10.1007/s11434-008-0097-8.

Garbulsky, M. F., Peñuelas, J., Papale, D., Filella, I., 2008. Remote estimation of carbon dioxide uptake 

2486.2008.01684.x.

504 Gilmanov, T. G., Aires, L., Barcza, Z., Baron, V. S., Belelli, L., Beringer, J., Billesbach, D., Bonal, D., 505 Bradford, J., Ceschia, E., Cook, D., Corradi, C., Frank, A., Gianelle, D., Gimeno, C., Gruenwald, T., 506 Guo, H., Hanan, N., Haszpra, L., Heilman, J., Jacobs, A., Jones, M. B., Johbson, D. A., Kiely, G., Li, 507 S., Magliulo, V., Moors, E., Nagy, Z., Nasyrov, M., Owensby, C., Pinter, K., Pio, C., Reichstein, M., 508 Sanz, M. J., Scott, R., Soussana, J. F., Stoy, P. C., Svejcar, T., 2010. Productivity, respiration, and 509 light-response parameters of world grassland and agroecosystems derived from flux-tower 510 measurements. Rangeland Ecology \& Management. 63, 16-39, http://dx.doi.org/10.2111/REM-D$511 \quad 09-00072.1$

512 Gioli, B., Miglietta, F., De Martino, B., Hutjes, R. W., Dolman, H. A., Lindroth, A., Schumacher, M., 513 Sanz, M. J., Manca, G., Peressotti, A., Dumas, E. J., 2004. Comparison between tower and aircraft514 based eddy covariance fluxes in five European regions. Agricultural and Forest Meteorology. 127, 1$515 \quad$ 16, http://dx.doi.org/10.1016/j.agrformet.2004.08.004.

516 Goetz, S. J., Prince, S. D., 1999. Modelling terrestrial carbon exchange and storage: evidence and 517 implications of functional convergence in light-use efficiency. Advances in Ecological Research. 28, 518 57-92, http://dx.doi.org/10.1016/S0065-2504(08)60029-X.

519 Goulden, M. L., McMillan, A. M. S., Winston, G. C., Rocha, A. V., Manies, K. L., Harden, J. W., Bond520 Lamberty, B. P., 2011. Patterns of NPP, GPP, respiration, and NEP during boreal forest succession. 521 Global Change Biology. 17, 855-871, http://dx.doi.org/10.1111/j.1365-2486.2010.02274.x. 522 Goulden, M. L., Winston, G. C., McMILlAN, A. N. D. R. E. W., Litvak, M. E., Read, E. L., Rocha, A. 523 V., Rob Elliot, J., 2006. An eddy covariance mesonet to measure the effect of forest age on land524 atmosphere exchange. Global Change Biology. 12, 2146-2162, http://dx.doi.org/10.1111/j.1365$525 \quad 2486.2006 .01251 . x$.

526 Grace, J., Nichol, C., Disney, M., Lewis, P., Quaife, T., Bowyer, P., 2007. Can we measure terrestrial 
photosynthesis from space directly, using spectral reflectance and fluorescence?. Global Change Biology. 13, 1484-1497, http://dx.doi.org/10.1111/j.1365-2486.2007.01352.x.

529

530

531

532

533

534

535

536

537

538

539

540

541

542
Greenberg, S. C. E., 1995. Understanding the Metropolis-Hastings algorithm. The American Statistician. 49, 327-335, http://dx.doi.org/10.2307/2684568.

Grünwald, T., Bernhofer, C., 2007. A decade of carbon, water and energy flux measurements of an old spruce forest at the anchor station tharandt. Tellus Series B-chemical \& Physical Meteorology. 59, 387-396, http://dx.doi.org/10.1111/j.1600-0889.2007.00259.x.

Gu, L., Meyers, T., Pallardy, S. G., Hanson, P. J., Yang, B., Heuer, M., Hosman, K. P., Riggs, J. S., Sluss, D., Wullschleger, S. D., 2006. Direct and indirect effects of atmospheric conditions and soil moisture on surface energy partitioning revealed by a prolonged drought at a temperate forest site. Journal of Geophysical Research: Atmospheres. 111, D16102, http://dx.doi.org/10.1029/2006JD007161.

Hammer, G. L., Wright, G. C., 1994. A theoretical analysis of nitrogen and radiation effects on radiation use efficiency in peanut. Australian Journal of Agricultural Research. 45, 575-589, http://dx.doi.org/10.1071/AR9940575.

Hashimoto, H., Wang, W., Milesi, C., Xiong, J., Ganguly, S., Zhu, Z., Nemani, R., 2013. Structural uncertainty in model-simulated trends of global gross primary production. Remote Sens. 5, 12581273, http://dx.doi.org/10.3390/rs5031258.

Haxeltine, A., Prentice, I. C., 1996. A general model for the light-use efficiency of primary production. Functional Ecology. 10, 551-561, http://dx.doi.org/10.2307/2390165.

He, M., Ju, W., Zhou, Y., Chen, J., He, H., Wang, S., Wang, H., Guan, D., Yan, J., Li, Y., Hao, Y., Zhao, F., 2013. Development of a two-leaf light use efficiency model for improving the calculation of terrestrial gross primary productivity. Agricultural \& Forest Meteorology. 173, 28-39, http://dx.doi.org/10.1016/j.agrformet.2013.01.003.

Heinsch, F.A., Reeves, M., Votava, P., Kang, S., Milesi, C., Zhao, M., Glassy, J., Jolly, W.M., Loehman, 

(MOD17A2/A3) Products NASA MODIS Land Algorithm. University of Montana, Numerical Terradynamic Simulation Group.

Hirano, T., Hirata, R., Fujinuma, Y., Saigusa, N., Yamamoto, S., Harazono, Y., Takada, M., Inukai, K. O. H., Inoue, G. E. N., 2003. CO2 and water vapor exchange of a larch forest in northern Japan. Tellus B. 55, 244-257, http://dx.doi.org/10.1034/j.1600-0889.2003.00063.x.

Honglin, H. E., Guirui, Y. U., Zhang, L., 2006. Simulating CO2 flux of three different ecosystems in ChinaFLUX based on artificial neural networks. Science in China. 49, 252-261, http://dx.doi.org/10.1007/s11430-006-8252-z.

Houborg, R., Anderson, M. C., Norman, J. M., Wilson, T., Meyers, T., 2009. Intercomparison of a 'bottom-up' and 'top-down' modeling paradigm for estimating carbon and energy fluxes over a variety of vegetative regimes across the U.S. Agricultural and Forest Meteorology. 149, 1875-1895, http://dx.doi.org/10.1016/j.agrformet.2009.06.014.

Huang, K., Wang, S., Zhou, L., Wang, H., Zhang, J., Yan, J., Zhao, L., Wang, Y., Shi, P., 2014. Impacts of diffuse radiation on light use efficiency across terrestrial ecosystems based on eddy covariance observation in china. Plos One. 9, e110988-e110988, http://dx.doi.org/10.1371/journal.pone.0110988.

Huete, A.R., Running, S., Myneni, R., 2006. Monitoring rainforest dynamics in the Amazon with MODIS land products. In: IEEE International Geoscience and Remote Sensing Symposium (IGARSS). IEEE International Geoscience and Remote Sensing Proceedings: Denver, CO, pp. 263265, http://dx.doi.org/10.1109/IGARSS.2006.72.

Hutyra, L. R., Munger, J. W., Hammond-Pyle, E., Saleska, S. R., Restrepo-Coupe, N., Daube, B. C., de Camargo P. B., Wofsy, S. C., 2008. Resolving systematic errors in estimates of net ecosystem exchange of $\mathrm{CO} 2$ and ecosystem respiration in a tropical forest biome. agricultural and forest meteorology. 148, 1266-1279, http://dx.doi.org/10.1016/j.agrformet.2008.03.007. 
Jassal, R. S., Black, T. A., Chen, B., Roy, R., Nesic, Z., Spittlehouse, D. L., Trofymow, J. A., 2008. $\mathrm{N} 2 \mathrm{O}$ emissions and carbon sequestration in a nitrogen - fertilized Douglas fir stand. Journal of Geophysical Research: Biogeosciences, 113, 373-381, http://dx.doi.org/10.1029/2008JG000764.

Kanniah, K. D., Beringer, J., Hutley, L. B., Tapper, N. J., Zhu, X., 2009. Evaluation of collections 4 and 5 of the modis gross primary productivity product and algorithm improvement at a tropical savanna site in northern australia. Remote Sensing of Environment. 113, 1808-1822, http://dx.doi.org/10.1016/j.rse.2009.04.013.

Kempf, J. S., Pickett, S. T. A., 1981. The role of branch length and angle in branching pattern of forest shrubs along a successional gradient. New Phytologist. 88, 111-116, http://dx.doi.org/10.1111/j.1469-8137.1981.tb04574.x.

Lafleur, P. M., Roulet, N. T., Bubier, J. L., Frolking, S., Moore, T. R., 2003. Interannual variability in the peatland - atmosphere carbon dioxide exchange at an ombrotrophic bog. Global Biogeochemical Cycles. 17, 109-124, http://dx.doi.org/10.1029/2002GB001983.

Landsberg, J. J., Waring, R. H., 1981. A generalised model of forest productivity using simplified concepts of radiation-use efficiency, carbon balance and partitioning. Forest Ecology \& Management. 95, 209-228, http://dx.doi.org/10.1016/S0378-1127(97)00026-1.

Lehuger, S., Gabrielle, B., Oijen, M. V., Makowski, D., Germon, J. C., Morvan, T., Hénault, C., 2009. Bayesian calibration of the nitrous oxide emission module of an agro-ecosystem model. Agriculture Ecosystems \& Environment. 133, 208-222, http://dx.doi.org/10.1016/j.agee.2009.04.022.

Lei, G., Peng, X. H., Peth, S., Horn, R., 2012. Effects of grazing intensity on soil water regime and flux in inner mongolia grassland, china. Pedosphere. 22, 165-177, http://dx.doi.org/10.1016/S10020160(12)60003-4.

Liang, S., Li, X., Wang, J. (Eds.)., 2012. Advanced remote sensing: terrestrial information extraction and applications. Academic Press. 
601 Muramatsu, K., Furumi, S., Soyama, N., Daigo, M., 2014. Estimating the seasonal maximum light use 602 efficiency. Proc. SPIE 9260, Land Surface Remote Sensing II, 92603R, 603 http://dx.doi.org/10.1117/12.2069142

604 Medlyn, B. E., 1998. Physiological basis of the light use efficiency model. Tree Physiology. 18, 167605 176, 10. http://dx.doi.org/1093/treephys/18.3.167.

606 Medlyn, B. E., Loustau, D., Delzon, S., 2002. Temperature response of parameters of a biochemically 607 based model of photosynthesis. i. seasonal changes in mature maritime pine ( pinus pinaster, ait.). 608 Plant Cell \& Environment. 25, 1155-1165, http://dx.doi.org/10.1046/j.1365-3040.2002.00890.x. 609 Merbold, L., Ziegler, W., Mukelabai, M. M., \& Kutsch, W. L., 2011. Spatial and temporal variation of 610 CO 2 efflux along a disturbance gradient in a miombo woodland in Western Zambia. Biogeosciences. $611 \quad$ 8, 147-164, http://dx.doi.org/10.5194/bg-8-147-2011.

612 Misson, L., Degueldre, D., Collin, C., Rodriguez, R., Rocheteau, A., Ourcival, J., Rambal, S., 2010. 613 Phenological responses to extreme droughts in a Mediterranean forest. Global Change Biology. 17, 614 1036-1048, http://dx.doi.org/10.1111/j.1365-2486.2010.02348.x.

615 Monk, C.D., Day, F. P., 1985. Vegetation analysis, primary production and selected nutrient budgets 616 for a southern Appalachian oak forest: A synthesis of IBP studies at Coweeta. Forest Ecology and 617 Management. 10, 87-113, http://dx.doi.org/10.1016/0378-1127(85)90015-5.

618 Monk, C.D., 1966. An ecological significance of evergreenness. Ecology. 47, 504-505, 619 http://dx.doi.org/10.2307/1932995.

620 Montaldo, N., Albertson, J. D., Mancini, M., 2007. Dynamic calibration with an ensemble Kalman 621 filter based data assimilation approach for root-zone moisture predictions. Journal of 622 Hydrometeorology. 8, 910-921, http://dx.doi.org/10.1175/JHM582.1.

623 Monteith, J.L., 1972. Solar radiation and productivity in tropical ecosystems. Journal of Applied $624 \quad$ Ecology. 9, 747-766.

625 Monteith, J.L., 1977. Climate and the efficiency of crop production in Britain. Philos. Trans. R. Soc. 
627 Norman, J. M., 1982. Simulation of microclimates. Biometeorology in integrated pest management.6599, http://dx.doi.org/10.1016/B978-0-12-332850-2.50009-8.

Odum, E. P., Barrett, G. W., Lu, J. J., 2009. Fundamentals of ecology.5, 87-88, 148.

Pilegaard, K., Mikkelsen, T. N., Beier, C., Jensen, N. O., Ambus, P., Ro-Poulsen, H., 2003. Field measurements of atmosphere-biosphere interactions in a Danish beech forest. Boreal Environment Research. 8, 315-334.

Potter, C. S., Rerson, J. T., Field, C. B., Matson, P. A., Vitousek, P. M., Mooney, H. A., Klooster, S. A., 1993. Terrestrial ecosystem production: a process model based on global satellite and surface data. Global Biogeochemical Cycles. 7, 811-841, http://dx.doi.org/10.1029/93GB02725.

Prince, S. D., Goward, S. N., 1995. Global primary production: a remote sensing approach. Journal of Biogeography. 22, 815-835, http://dx.doi.org/10.2307/2845983.

Raczka, B. M., Davis, K. J., Huntzinger, D., Neilson, R. P., Poulter, B., Richardson, A. D., Xiao, J., Tomelleri, E., Verbeeck, H., Viovy, N., 2013. Evaluation of continental carbon cycle simulations with North American flux tower observations. Ecological Monographs. 83, 531-556, http://dx.doi.org/10.1890/12-0893.1. New York,pp. 44-57.

Running, S.W., Nemani, R., Heinsch, F.A., Zhao, M., Reeves, M.C., Hashimoto, H., 2004. A Running, S. W., Thornton, P. E., Nemani, R., Glassy, J. M., 2000. Global Terrestrial Gross and Net continuous satellite-derived measure of global terrestrial primary production. BioScience. 54, 547560, http://dx.doi.org/10.1641/0006-3568(2004)054[0547:ACSMOG]2.0.CO;2.

Saitoh, T. M., Nagai, S., Yoshino, J., Kondo, H., Tamagawa, I., Muraoka, H., 2015. Effects of canopy 650 phenology on deciduous overstory and evergreen understory carbon budgets in a cool-temperate 

http://dx.doi.org/10.1007/s11284-014-1229-z.

653 Schwalm, C. R., Black, T. A., Morgenstern, K., Humphreys, E. R., 2007. A method for deriving net 654 primary productivity and component respiratory fluxes from tower-based eddy covariance data: A 655 case study using a 17-year data record from a Douglas-fir chronosequence. Global Change Biology. 656 13, 370-385, http://dx.doi.org/10.1111/j.1365-2486.2006.01298.x.

657 Schwalm, C. R.,Williams, C. A., Schaefer, K., Anderson, R., Arain,M. A., Baker, I., Barr, A., Black, T. 658 A., Chen, G., Chen, J. M., Ciais, P., Davis, K. J., Desai, A., Dietze, M., Dragoni, D., Fischer, M. L., 659 Flanagan, L. B., Grant, R., Gu, L., Hollinger, D., Izaurralde, R. C., Kucharik, C., Lafleur, P., Law, B. 660 E., Li, L., Li, Z., Liu, S., Lokupitiya, E., Luo, Y., Ma, S., Margolis, H., Matamala, R., McCaughey, 661 H., Monson, R. K., Oechel, W. C., Peng, C., Poulter, B., Price, D. T., Riciutto, D. M., Riley, W., 662 Sahoo, A. K., Sprintsin, M., Sun, J., Tian, H., Tonitto, C., Verbeeck, H., and Verma, S. B.,2010. A 663 model data intercomparison of $\mathrm{CO}_{2}$ exchange across North America: Results from the North 664 American Carbon Program site synthesis, Journal of Geophysical Research Atmospheres. 115, 665 G00H05, http://dx.doi.org/10.1029/2009JG001229.

666 Scott, R. L., 2010. Using watershed water balance to evaluate the accuracy of eddy covariance 667 evaporation measurements for three semiarid ecosystems. Agricultural and Forest Meteorology. 150, 668 219-225, http://dx.doi.org/10.1016/j.agrformet.2009.11.002.

669 Sinclair, T. R., Shiraiwa, T., 1993. Soybean radiation-use efficiency as influenced by nonuniform 670 specific leaf nitrogen distribution and diffuse radiation. Crop Science. 33, 808-812, 671 http://dx.doi.org/10.2135/cropsci1993.0011183X003300040036x.

672 Smith, P., Lanigan, G., Kutsch, W. L., Buchmann, N., Eugster, W., Aubinet, M., Ceschia, E., Béziat, 673 P., Yeluripati, J. B., Osborne, B., 2010. Measurements necessary for assessing the net ecosystem 674 carbon budget of croplands. Agriculture, Ecosystems \& Environment. 139, 302-315, 
676 Stagakis, S., Markos, N., Sykioti, O., Kyparissis, A., 2014. Tracking seasonal changes of leaf and 677 canopy light use efficiency in a phlomis fruticosa, mediterranean ecosystem using field

678 measurements and multi-angular satellite hyperspectral imagery. Isprs Journal of Photogrammetry \& 679 Remote Sensing. 97, 138-151, http://dx.doi.org/10.1016/j.isprsjprs.2014.08.012.

680 Sulkava, M., Luyssaert, S., Zaehle, S., Papale, D., 2011. Assessing and improving the 681 representativeness of monitoring networks: the european flux tower network example. Journal of 682 Geophysical Research Biogeosciences. 116, 278-278, http://dx.doi.org/10.1029/2010JG001562. 683 Sulkava, M., Luyssaert, S., Zaehle, S., Papale, D., 2011. Assessing and improving the 684 representativeness of monitoring networks: the european flux tower network example. Journal of 685 Geophysical Research Biogeosciences. 116, 278-278, http://dx.doi.org/10.1029/2010JG001562. 686 Svensson, M., Jansson, P. E., Gustafsson, D., Dan, B. K., Langvall, O., Lindroth, A., 2008. Bayesian 687 calibration of a model describing carbon, water and heat fluxes for a swedish boreal forest stand. 688 Ecological Modelling. 213, 331-344, http://dx.doi.org/10.1016/j.ecolmodel.2008.01.001.

689 Tang, S., Chen, J. M., Zhu, Q., Li, X., Chen, M., Sun, R., Zhou, Y., Deng, F., Xie, D., 2007. Lai 690 inversion algorithm based on directional reflectance kernels. Journal of Environmental Management, $691 \quad$ 85(3), 638-48, http://dx.doi:10.1016/j.jenvman.2006.08.018.

692 Taylor, K. E., 2001. Summarizing multiple aspects of model performance in a single diagram. Journal 693 of Geophysical Research Atmospheres. 106, 7183-7192, http://dx.doi.org/10.1029/2000JD900719. 694 Teh, C. B. S., Simmonds, L. P., Wheeler, T. R., 2000. An equation for irregular distributions of leaf 695 azimuth density. Agricultural and Forest Meteorology. 102, 223-234, 696 http://dx.doi.org/10.1016/S0168-1923(00)00132-5.

697 Tsubo, M. and S.Walker (2005), Relationships between photosynthetically active radiation and 698 clearness index at Bloemfontein, South Africa, Theoretical and Applied Climatology, 80(1), 17-25, 699 http://dx.doi.org/10.1007/s00704-004-0080-5. 
700 Thurner, M., Beer, C., Santoro, M., Carvalhais, N., Wutzler, T., Schepaschenko, D., Shvidenko, A. Z.,

701 Kompter, E., Ahrens, B., Levick, S. R.,Schmullius, C. C., 2014. Carbon stock and density of 702 northern boreal and temperate forests. Global Ecology \& Biogeography. 23, 297-310, 703 http://dx.doi.org/10.1111/geb.12125.

704 Valentini, R., Angelis, P. D., Matteucci, G., Monaco, R., Dore, S., Mucnozza, G. S., 1996. Seasonal net 705 carbon dioxide exchange of a beech forest with the atmosphere. Global Change Biology. 2, 199-207, 706 http://dx.doi.org/10.1111/j.1365-2486.1996.tb00072.x.

707 Van Oijen, M., Rougier, J., Smith, R., 2005. On Bayesian calibration and evaluation of process-based 708 forest models: bridging the gap between models and data. Tree Physiol. 25, 915-927, 709 http://dx.doi.org/10.1093/treephys/25.7.915.

710 Veenendaal, E. M., Kolle, O. L. A. F., Lloyd, J., 2004. Seasonal variation in energy fluxes and carbon 711 dioxide exchange for a broad-leaved semi-arid savanna (Mopane woodland) in Southern Africa. 712 Global Change Biology. 10, 318-328, http://dx.doi.org/10.1111/j.1365-2486.2003.00699.x. 713 Weiss, A., Norman, J.M., 1985. Partitioning solar radiation into direct and diffuse, visible and near714 infrared components. Agr. Forest Meteorol. 34, 205-213. http://dx.doi.org/10.1016/0168715 1923(85)90020-6

716 Whitney, G.G., 1976. The bifurcation ratio as an indicator of adaptive strategy in woody plant species. 717 Bulletin of the Torrey Botanical Club. 103, 67-72, http://dx.doi.org/10.2307/2484833.

718 Willmott, C. J., 2010. Some comments on the evaluation of model performance. Bulletin of the 719 American Meteorological Society. 63, 1309-1369, http://dx.doi.org/10.1175/1520$720 \quad$ 0477(1982)0632.0.CO;2.

721 Willmott, C. J., Ackleson, S. G., Davis, R. E., Feddema, J. J., Klink, K. M., Legates, D. R., Donnell, J. 722 O., Rowe, C. M., 1985. Statistics for the evaluation and comparison of models. Journal of 723 Geophysical Research Atmospheres. 90, 8995-9005, http://dx.doi.org/10.1029/JC090iC05p08995. 724 Willmott, C. J., Matsuura, K., 2005. Advantages of the mean absolute error (mae) over the root mean 
square error (rmse) in assessing average model performance. Climate Research. 30, 79-82, http://dx.doi.org/10.3354/cr030079.

727

728

729

730

731

732

733

734

735

736

737

738

739

740

741

742

743

744

745

746

747

Wilson, K. B., Baldocchi, D. D., Hanson, P. J., 2000. Spatial and seasonal variability of photosynthetic parameters and their relationship to leaf nitrogen in a deciduous forest. Tree Physiology. 20, 565-578, http://dx.doi.org/10.1093/treephys/20.9.565.

Wohlfahrt, G., Fenstermaker, L. F., Arnone Iii, J. A., 2008. Large annual net ecosystem co2 uptake of a mojave desert ecosystem. Global Change Biology. 14, 1475-1487, http://dx.doi.org/10.1111/j.13652486.2008.01593.x.

Wu, C., Munger, J. W., Niu, Z., Kuang, D., 2010. Comparison of multiple models for estimating gross primary production using modis and eddy covariance data in harvard forest. Remote Sensing of Environment. 114, 2925-2939, http://dx.doi.org/10.1016/j.rse.2010.07.012.

Xiao, X., Hollinger, D., Aber, J., Goltz, M., Davidson, E. A., Zhang, Q., III, B. M., 2004. Satellitebased modeling of gross primary production in an evergreen needleleaf forest. Remote Sensing of Environment. 89, 519-534, http://dx.doi.org/10.1016/j.rse.2003.11.008.

Xiao, X., Zhang, Q., Hollinger, D., Aber, J., Moore, B., 2005. Modeling gross primary production of an evergreen needleleaf forest using modis and climate data. Ecological Applications. 15, 954-969, http://dx.doi.org/10.1890/04-0470.

Xu, G., Zhang, H., Chen, B., Zhang, H., Yan, J., Chen, J., Che, M., Lin, X., Dou, X., 2014. A bayesian based method to generate a synergetic land-cover map from existing land-cover products. Remote Sensing. 6, 5589-5613, http://dx.doi.org/10.3390/rs6065589.

Xu, L., Baldocchi, D. D., 2003. Seasonal trends in photosynthetic parameters and stomatal conductance of blue oak (quercus douglasii) under prolonged summer drought and high temperature. Tree Physiology. 23, 865-77, http://dx.doi.org/10.1093/treephys/23.13.865. 
Yi, X., \& Yang, Y., 2006. A stable carbon isotopic approach for understanding the $\mathrm{CO}_{2}$ flux at the 749 haibei alpine meadow ecosystem — a simple model. Ecological Modelling, 193(3-4), 796-800. doi:10.1016/j.ecolmodel.2005.07.014

751

Yuan, W., Cai, W., Xia, J., Chen, J., Liu, S., Dong, W., Merbold, L., Law, B., Arain, A., Beringer, J., Bernhofer, C., Black, A., Blanken, P. D., Cescatti, A., Chen, Y., Francois, L., Gianelle, D., Janssens, I. A., Jung, M., Kato, T., Kiely, G., Liu, D., Marcolla, B., Montagnani, L., Raschi, A., Roupsard, O., Varlagin, A., Wohlfahrt, G., 2014. Global comparison of light use efficiency models for simulating terrestrial vegetation gross primary production based on the lathuile database. Agricultural \& Forest Meteorology. s 192-193, 108-120, http://dx.doi.org/10.1016/j.agrformet.2014.03.007.

Yuan, W., Liu, S., Zhou, G., Zhou, G., Tieszen, L. L., Baldocchi, D., Bernhofer, C., Gholz, H.,Goldstein, A. H., Goulden, M. L., Hollinger, D. Y., Hu, Y., Law, B. E., Stoy, P. C., Vesala, T., Wofsy, S. C.,collaborators, o. A., 2007. Deriving a light use efficiency model from eddy covariance flux data for predicting daily gross primary production across biomes. Agricultural \& Forest Meteorology. 143, 189-207, http://dx.doi.org/10.1016/j.agrformet.2006.12.001.

Zhang, L. X., Zhou, D. C., Fan, J. W., Hu, Z. M., 2015. Comparison of four light use efficiency models for estimating terrestrial gross primary production. Ecological Modelling. 300, 30-39, http://dx.doi.org/10.1016/j.ecolmodel.2015.01.001.

Zhang, L., Luo, Y., Yu, G., Zhang, L., 2010. Estimated carbon residence times in three forest ecosystems of eastern china: applications of probabilistic inversion. Journal of Geophysical Research. 115, 137-147, http://dx.doi.org/10.1029/2009JG001004.

Zhao, M., Running, S.W., 2010. Drought-induced reduction in global terrestrial net primary production from 2000 through 2009. Science. 329, 940-943, http://dx.doi.org/10.1126/science.1192666.

Zhou, Y., Wu, X., Ju, W., Chen, J. M., Wang, S., \& Wang, H., Yuan, W., Black, A., Jassal, R., Ibrom, A., Han, S., Yan, J., Margolis, H., Roupsard, O., Li, Y., Zhao, F., Kiely, G., Starr, G., Pavelka, M., Montagnani, L.,Wohlfahrt, G., D'Odorico, P., Cook, D., Arain, M., Bonal, D., Beringer, J., Blanken, 
773 P., Loubet, B., Leclerc, M., Matteucci, G., Nagt, Z., Olejnik, J., U, K. P., Varlagin, A., 2015. Global

774 parameterization and validation of a two - leaf light use efficiency model for predicting gross

775 primary production across fluxnet sites. Journal of Geophysical Research Biogeosciences.

776 http://dx.doi.org/10.1002/2014JG002876.

777 Zhu, G. F., Li, X., Su, Y. H., Lu, L., \& Huang, C. L., 2011. Seasonal fluctuations and temperature

778 dependence in photosynthetic parameters and stomatal conductance at the leaf scale of populus

779 euphratica oliv. Tree Physiology. 31, 178-95, http://dx.doi.org/10.1093/treephys/tpr005.

780 Zhu, Z., Bi, J., Pan, Y., Ganguly, S., 2013. Global data sets of vegetation leaf area index (lai)3g and

781 fraction of photosynthetically active radiation (fpar)3g derived from global inventory modeling and

782 mapping studies (gimms) normalized difference vegetation index (ndvi3g) for the period 1981 to

783 2011. Remote Sensing, 5(2), 927-948, http://dx.doi.org/10.3390/rs5020927.

784 


\section{Figures and Tables}

786 Table 1.

787 ID, climate type, vegetation type and other characteristics of the study sites used for model calibration

788 and validation.

\begin{tabular}{|c|c|c|c|c|c|c|c|}
\hline Site ID ${ }^{a}$ & $\operatorname{Lat}\left({ }^{\circ} \mathrm{N}\right)$ & $\operatorname{Lon}\left({ }^{\circ} \mathrm{E}\right)$ & $\operatorname{Elev}(\mathrm{m})$ & $\begin{array}{l}\text { PFTs (Biomes } \\
\text { Types b and Climate } \\
\text { Zones) }\end{array}$ & $\begin{array}{c}\text { Average annual } \\
\text { Temperature } \\
\left({ }^{\circ} \mathrm{C}\right) \\
\end{array}$ & $\begin{array}{l}\text { Precipitation } \\
\quad\left(\mathrm{mm} \cdot \mathrm{yr}^{-1}\right)\end{array}$ & References \\
\hline CA-Ca1 & 49.867 & -125.334 & 313 & Temperate-NEF & 9.93 & 1456 & Schwalm et al., 2007 \\
\hline $\mathrm{CA}-\mathrm{Ca} 3$ & 49.534 & -124.900 & 120 & Temperate-NEF & 9.94 & 1683 & Jassal et al., 2008 \\
\hline DE-Tha & 50.964 & 13.567 & 380 & Temperate-NEF & 7.70 & 804 & Grünwald et al., 2007 \\
\hline CN-Qia & 26.741 & 115.058 & 64 & Temperate-NEF & 18.95 & 1467 & Zhang et al., 2010 \\
\hline ES-ES1 & 39.346 & -0.319 & 1 & Mediterranean-NEF & 17.69 & 457 & Berbigier et al., 2001 \\
\hline CA-Obs & 53.987 & -105.118 & 629 & Boreal-NEF & 0.79 & 406 & Brümmer et al., 2012 \\
\hline CA-Qfo & 49.693 & -74.342 & 382 & Boreal-NEF & -0.36 & 962 & Raczka et al., 2013 \\
\hline CA-Ojp & 53.916 & -104.692 & 579 & Boreal-NEF & 0.12 & 431 & Barr et al., 2013 \\
\hline CA-NS1 & 55.879 & -98.484 & 253 & Boreal-NDF & -2.89 & 500 & COURSOLLE et al., 2012 \\
\hline FI-Hyy & 61.847 & 24.295 & 185 & Boreal-NDF & 3.80 & 709 & Sulkava et al., 2012 \\
\hline RU-Ylr & 62.255 & 129.241 & 214 & Boreal-NDF & -10.37 & 241 & Eugster et al., 2000 \\
\hline FR-Pue & 43.741 & 3.596 & 270 & Mediterranean-BEF & 13.50 & 883 & Misson et al., 2010 \\
\hline IT-Cpz & 41.705 & 12.376 & 9 & Mediterranean-BEF & 15.99 & 778 & Garbulsky et al., 2008 \\
\hline BR-Sa1 & -2.857 & -54.959 & 90 & Tropical-BEF & 26.13 & 2075 & Hutyra et al., 2008 \\
\hline BR-Sa3 & -3.018 & -54.971 & 100 & Tropical-BEF & 26.12 & 2044 & Fisher et al., 2009 \\
\hline TH-Sak & 14.492 & 101.916 & 470 & Tropical-BEF & 24.37 & 1027 & Fisher et al., 2009 \\
\hline US-Los & 46.083 & -89.979 & 485 & Temperate-BDF & 4.08 & 828 & Bakwin et al., 2004 \\
\hline $\mathrm{CH}-\mathrm{Lae}$ & 47.478 & 8.365 & 645 & Temperate-BDF & 7.80 & 1222 & Smith et al., 2010 \\
\hline JP-Tak & 36.146 & 137.423 & 1355 & Temperate-BDF & 6.54 & 1024 & Saitoh et al., 2015 \\
\hline IT-Co1 & 41.849 & 13.588 & 1645 & Mediterranean-BDF & 7.32 & 971 & Valentini et al., 1996 \\
\hline US-MOz & 38.744 & -92.200 & 212 & Mediterranean-BDF & 12.11 & 986 & Gu et al., 2006 \\
\hline DE-Gri & 50.949 & 13.513 & 385 & Boreal-BDF & 7.20 & 853 & Gilmanov e et al., 2010 \\
\hline DE-Hai & 51.079 & 10.452 & 430 & Boreal-BDF & 8.30 & 720 & Gioli et al., 2004 \\
\hline DK-Sor & 55.487 & 11.646 & 40 & Boreal-BDF & 8.20 & 660 & Pilegaard et al., 2003 \\
\hline CA-Oas & 53.629 & -106.198 & 580 & Boreal-BDF & 0.34 & 429 & Barr et al., 2007 \\
\hline Th-Mae & 14.576 & 98.844 & 231 & Tropical-BDF & 26.02 & 2266 & Huete et al., 2006 \\
\hline ZM-Mon & -15.438 & 23.253 & 1094 & Tropical-BDF & 25.00 & 945 & Merbold et al., 2011 \\
\hline CA-Mer & 45.409 & -75.519 & 65 & Temperate-BDS & 6.07 & 891 & Lafleur et al., 2003 \\
\hline CA-NS6 & 55.917 & -98.964 & 244 & Boreal-BDS & -3.08 & 495 & Goulden et al., 2006 \\
\hline BW-Ma1 & -19.916 & 23.561 & 13.5 & Tropical-SAV & 22.00 & 493 & Veenendaal et al., 2004 \\
\hline CG-Tch & -4.289 & 11.656 & 1 & Tropical-SAV & 25.70 & 1150 & Ciais et al., 2011 \\
\hline ZA-Kru & -25.020 & 31.497 & 357 & Tropical-SAV & 21.90 & 547 & Archibald et al., 2009 \\
\hline JP-Tom & 42.737 & 141.521 & 115 & Temperate-MF & 6.72 & 1156 & Hirano et al., 2003 \\
\hline CN-Cha & 42.403 & 128.096 & 745 & Temperate-MF & 2.16 & 664 & Zhang et al., 2010 \\
\hline BE-Vie & 50.306 & 5.997 & 450 & Boreal-MF & 7.80 & 1062 & Sulkava et al., 2011 \\
\hline CA-Gro & 48.217 & -82.156 & 340 & Boreal-MF & 1.30 & 831 & Bernier et al., 2006 \\
\hline AT-Neu & 47.116 & 11.320 & 970 & $\mathrm{C}_{3}$ grass & 6.30 & 852 & Wohlfahrt et al., 2008 \\
\hline CN-Nmg & 43.500 & 117.450 & 1720 & $\mathrm{C}_{3}$ grass & 0.70 & 343 & Lei et al., 2012 \\
\hline IE-Dri & 51.987 & -8.752 & 187 & $\mathrm{C}_{3}$ grass & 9.18 & 1084 & Montaldo et al., 2007 \\
\hline US-Ton & 38.432 & -120.966 & 177 & $\mathrm{C}_{3}$ and $\mathrm{C}_{4}$ grass & 15.80 & 559 & Fisher et al., 2008 \\
\hline US-FPe & 48.308 & -74.434 & 638 & $\mathrm{C}_{3}$ and $\mathrm{C}_{4}$ grass & 5.48 & 335 & Gilmanov et al., 2010 \\
\hline US-Wkg & 31.736 & 109.942 & 1531 & $\mathrm{C}_{3}$ and $\mathrm{C}_{4}$ grass & 15.64 & 407 & Scott, 2010 \\
\hline FI-Kaa & 69.141 & 27.295 & 155 & $\mathrm{C}_{3}$ grass, arctic & -1.40 & 454 & Aurela et al., 2001 \\
\hline $\mathrm{CN}-\mathrm{Hab}$ & 37.613 & 101.305 & 3183 & $\mathrm{C}_{3}$ grass, arctic & 1.43 & 351 & Yi et al., 2006 \\
\hline
\end{tabular}

${ }^{\mathrm{a}}$ The site ID are taken from FLUXNET.

$790{ }^{b}$ Biome types: needleleaf evergreen forest (NEF), needleleaf deciduous forest (NDF), broadleaf evergreen forest (BEF), broadleaf 791 deciduous forest (BDF), broadleaf deciduous shrub (BDS), grassland $\left(\mathrm{C}_{3}\right.$ grass, $\mathrm{C}_{3}$ and $\mathrm{C}_{4}$ grass, $\mathrm{C}_{3}$ grass, arctic), Mixed forest (MF), 792 savanna $(\mathrm{SAV})$. 
794 Table 2.

795 Plant Functional Types, Climate Rules and Dependent parameters used in light use efficiency models

796 for GPP estimation, including $\varepsilon_{\max }, V P D_{\max }, V P D_{\min }, T_{\max }, T_{\min }$, albedo $(\alpha)$ and clumping index $(\Omega)$ of

797 different plant functional types (PFTs).

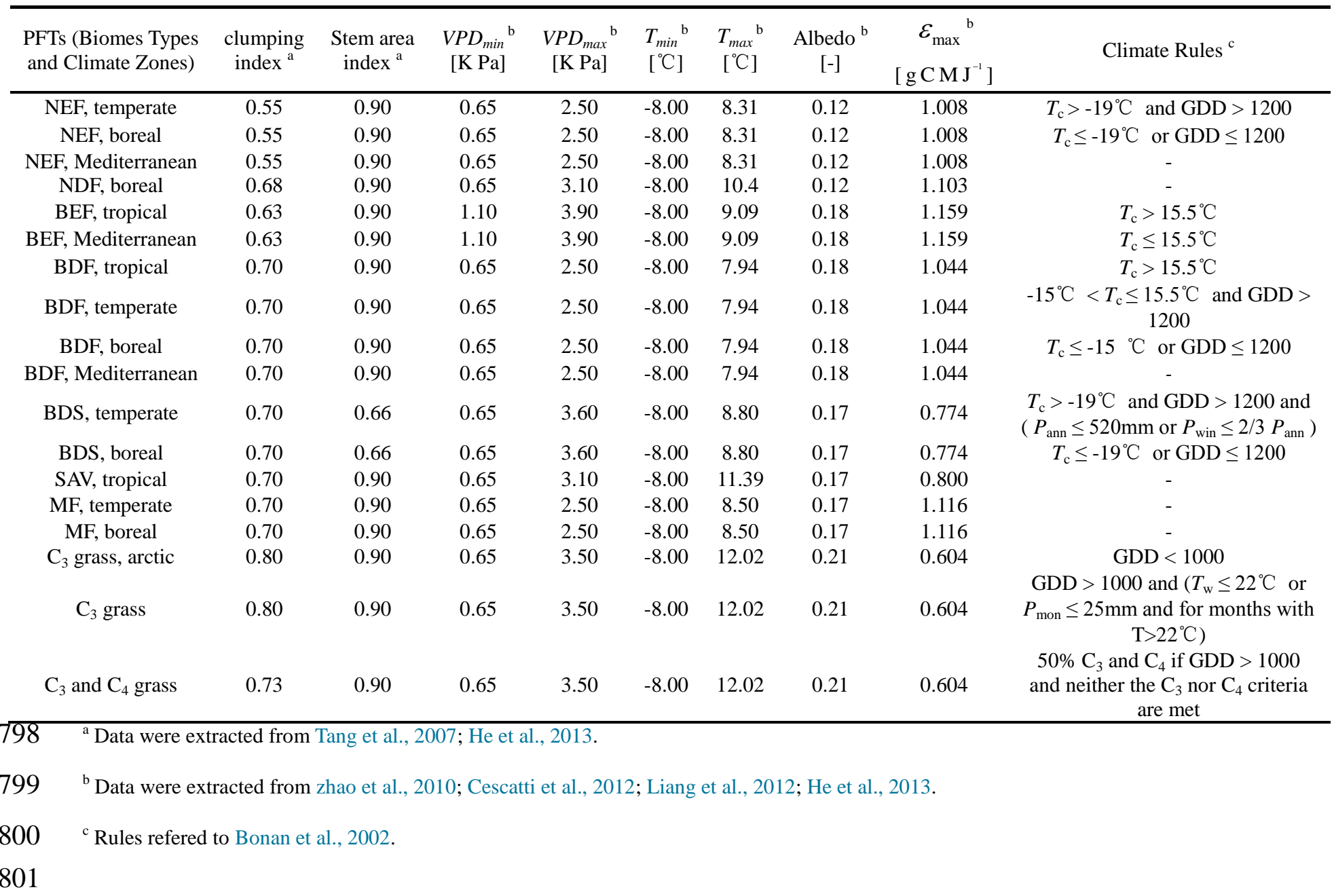


802 Table 3.

803 The coefficients of variation $(\mathrm{CV}=$ standard deviations/mean $\times 100 \%)$ of the optimized posterior

804 probability distribution of the maximum LUE $\left(\varepsilon_{\max }\right)$, maximum LUE of sunlit and shaded leaves

$805\left(\varepsilon_{m s u}\right.$ and $\left.\varepsilon_{m s h}\right)$ for different PFTs in four seasons.

\begin{tabular}{|c|c|c|c|c|c|c|c|c|c|c|c|c|}
\hline \multirow{3}{*}{$\begin{array}{l}\text { Plant Funtional Types } \\
\text { (PFTs) }\end{array}$} & \multicolumn{12}{|c|}{ Coefficients of variation $(\mathrm{CV}, \%)$} \\
\hline & \multicolumn{4}{|c|}{$\varepsilon_{\max }\left(\mathrm{gC} \cdot \mathrm{MJ}^{-1}\right)$} & \multicolumn{4}{|c|}{$\varepsilon_{m s u}\left(\mathrm{gC} \cdot \mathrm{MJ}^{-1}\right)$} & \multicolumn{4}{|c|}{$\varepsilon_{m s h}\left(\mathrm{gC} \cdot \mathrm{MJ}^{-1}\right)$} \\
\hline & Spr. & Sum. & Fall & Win. & Spr. & Sum. & Fall & Win. & Spr. & Sum. & Fall & Win. \\
\hline Boreal-BDF & 43.22 & 9.18 & 45.23 & $-{ }^{\mathrm{a}}$ & 75.38 & 7.08 & 97.43 & - & 24.34 & 11.14 & 37.58 & - \\
\hline Boreal-NDF & 28.32 & 4.06 & 0.02 & - & 2.65 & 34.16 & 30.18 & - & 2.03 & 28.67 & 51.37 & - \\
\hline Mediterranean-BDF & 30.73 & 8.22 & 24.41 & - & 50.41 & 26.3 & 23.81 & - & 21.28 & 47.48 & 17.23 & - \\
\hline Temperate-BDF & 18.01 & 13.74 & 57.49 & - & 34.24 & 10.22 & 128.9 & - & 21.98 & 12.05 & 10.80 & - \\
\hline Tropical-BDF & 23.53 & 6.39 & 16.3 & - & 22.6 & 8.98 & 38.51 & - & 44.88 & 11.87 & 2.49 & - \\
\hline Boreal-BDS & 102.5 & 7.26 & 41.39 & - & 74.01 & 23.62 & 26.28 & - & 58.97 & 11.30 & 40.58 & - \\
\hline Temperate-BDS & 53.87 & 5.58 & 20.67 & - & 74.19 & 30.35 & 31.92 & - & 46.39 & 25.74 & 27.47 & - \\
\hline Boreal-NEF & 87.75 & 6.59 & 53.51 & 29.85 & 62.76 & 44.26 & 44.65 & 26.34 & 90.40 & 23.04 & 50.30 & 26.95 \\
\hline Mediterranean-BEF & 8.31 & 24.17 & 20.19 & 3.82 & 6.140 & 43.45 & 51.35 & 23.30 & 13.20 & 16.08 & 38.38 & 21.16 \\
\hline Mediterranean-NEF & 5.39 & 20.04 & 5.87 & 11.17 & 21.37 & 27.83 & 16.20 & 66.19 & 11.41 & 12.57 & 18.28 & 23.83 \\
\hline Temperate-NEF & 4.54 & 6.08 & 4.28 & 22.68 & 26.08 & 35.96 & 56.80 & 139.5 & 9.45 & 2.92 & 13.03 & 7.12 \\
\hline Tropical-BEF & 22.58 & 7.64 & 5.23 & 16.35 & 67.57 & 66.13 & 56.95 & 33.01 & 9.49 & 3.57 & 7.08 & 17.79 \\
\hline Boreal-MF & 6.93 & 12.64 & 12.74 & 53.04 & 61.26 & 61.36 & 75.19 & 51.45 & 28.82 & 6.40 & 9.12 & 30.10 \\
\hline Temperate-MF & 96.97 & 13.94 & 60.83 & 23.66 & 100.9 & 39.68 & 62.74 & 31.45 & 68.09 & 9.81 & 29.72 & 54.63 \\
\hline C3-C4-grass & 17.6 & 23.74 & 45.28 & 90.81 & 55.84 & 19.44 & 54.24 & 74.95 & 23.98 & 41.74 & 28.52 & 75.44 \\
\hline $\mathrm{C} 3$-grass & 10.64 & 20.67 & 13.94 & 14.03 & 9.66 & 55.47 & 35.48 & 15.87 & 18.35 & 9.48 & 24.66 & 15.92 \\
\hline C3-grassArctic & 10.73 & 33.33 & 71.82 & 48.54 & 16.78 & 22.29 & 58.38 & 69.33 & 121.0 & 18.57 & 115.4 & 48.25 \\
\hline Tropical-SAV & 45.43 & 0.47 & 26 & 22.39 & 82.10 & 44.20 & 37.96 & 16.39 & 33.39 & 85.81 & 10.42 & 73.85 \\
\hline
\end{tabular}

806 Note: ${ }^{a}$ parameterization from March to November for deciduous vegetations, from January to December for other vegetations. 
808 Table 4.

809 Bias and root-mean-square error (RMSE) of half-hourly GPP (in $\mu \mathrm{mol} \cdot \mathrm{m}^{-2} \cdot \mathrm{s}^{-1}$ ) with respect to

810 individual months and seasons.

\begin{tabular}{ccc|cc|cc}
\hline \multirow{2}{*}{$\begin{array}{c}\text { Months } \\
\text { /Seasons }\end{array}$} & \multicolumn{2}{c|}{ LUE $_{\text {def }}$} & \multicolumn{2}{c|}{ SL-LUE } & \multicolumn{2}{c}{ TL-LUE } \\
\cline { 2 - 7 } Jan. & $-0.38( \pm 0.81)^{\text {a }}$ & $1.79( \pm 1.45)$ & $-0.29( \pm 0.39)$ & $1.57( \pm 1.33)$ & $-0.21( \pm 0.22)$ & $1.39( \pm 0.96)$ \\
Feb & $-0.59( \pm 1.14)$ & $2.31( \pm 1.79)$ & $-0.38( \pm 0.48)$ & $1.85( \pm 1.65)$ & $-0.25( \pm 0.35)$ & $1.61( \pm 1.42)$ \\
Mar. & $-0.21( \pm 1.01)$ & $2.41( \pm 1.51)$ & $-0.35( \pm 0.44)$ & $1.82( \pm 1.47)$ & $-0.30( \pm 0.38)$ & $1.69( \pm 1.23)$ \\
Apr. & $\mathbf{0 . 2 4}( \pm 1.17)$ & $\mathbf{3 . 1 0}( \pm 1.34)$ & $\mathbf{- 0 . 4 3} \pm \pm 0.38)$ & $\mathbf{2 . 2 1}( \pm 1.31)$ & $\mathbf{- 0 . 2 9}( \pm 0.26)$ & $\mathbf{1 . 9 7}( \pm 1.07)$ \\
May. & $-0.46( \pm 1.57)$ & $3.95( \pm 1.71)$ & $-0.64( \pm 0.43)$ & $3.20( \pm 1.65)$ & $-0.41( \pm 0.40)$ & $2.81( \pm 1.50)$ \\
Jun. & $-1.53( \pm 1.74)$ & $4.42( \pm 2.20)$ & $-0.96( \pm 0.62)$ & $3.90( \pm 1.88)$ & $-0.59( \pm 0.43)$ & $3.40( \pm 1.55)$ \\
Jul. & $-1.42( \pm 1.72)$ & $4.22( \pm 2.30)$ & $-0.89( \pm 0.61)$ & $3.60( \pm 1.92)$ & $-0.53( \pm 0.37)$ & $3.12( \pm 1.60)$ \\
Aug. & $-1.05( \pm 1.54)$ & $3.98( \pm 2.05)$ & $-0.79( \pm 0.53)$ & $3.35( \pm 1.69)$ & $-0.47( \pm 0.33)$ & $2.86( \pm 1.40)$ \\
Sep. & $-0.73( \pm 1.32)$ & $3.57( \pm 1.98)$ & $-0.61( \pm 0.42)$ & $2.98( \pm 1.70)$ & $-0.37( \pm 0.28)$ & $2.60( \pm 1.50)$ \\
Oct & $-0.23( \pm 0.78)$ & $2.68( \pm 1.48)$ & $-0.41( \pm 0.35)$ & $2.30( \pm 1.31)$ & $-0.25( \pm 0.26)$ & $2.04( \pm 1.14)$ \\
Nov. & $-0.19( \pm 0.16)$ & $1.94( \pm 1.33)$ & $-0.30( \pm 0.32)$ & $1.61( \pm 1.26)$ & $-0.23( \pm 0.22)$ & $1.47( \pm 1.05)$ \\
Dec. & $-0.25( \pm 0.67)$ & $1.75( \pm 1.31)$ & $-0.19( \pm 0.41)$ & $1.49( \pm 1.29)$ & $-0.10( \pm 0.27)$ & $1.40( \pm 1.12)$ \\
Winter ${ }^{b}$ & $-0.32( \pm 0.73)$ & $1.78( \pm 1.38)$ & $-0.23( \pm 0.38)$ & $1.48( \pm 1.30)$ & $-0.15( \pm 0.23)$ & $1.35( \pm 1.06)$ \\
Spring & $-0.16( \pm 1.05)$ & $\mathbf{3 . 0 6}( \pm 1.42)$ & $-0.43( \pm 0.37)$ & $\mathbf{2 . 3 8}( \pm 1.32)$ & $-0.30( \pm 0.28)$ & $\mathbf{2 . 1 0}( \pm 1.13)$ \\
Summer & $-1.19( \pm 1.53)$ & $\mathbf{3 . 8 8}( \pm 2.08)$ & $-0.79( \pm 0.54)$ & $\mathbf{3 . 2 9}( \pm 1.67)$ & $-0.51( \pm 0.33)$ & $\mathbf{2 . 8 9}( \pm 1.36)$ \\
Fall & $-0.35( \pm 0.70)$ & $2.67( \pm 1.43)$ & $-0.39( \pm 0.32)$ & $2.25( \pm 1.24)$ & $-0.25( \pm 0.20)$ & $1.97( \pm 1.03)$ \\
All year & $-0.51( \pm 0.30)$ & $2.95( \pm 1.37)$ & $-0.52( \pm 0.33)$ & $2.73( \pm 1.25)$ & $-0.33( \pm 0.23)$ & $2.40( \pm 1.05)$ \\
\hline
\end{tabular}

811 Note: ${ }^{a}$ Values in parentheses are standard deviations. ${ }^{b}$ Winter is composed of December, January and February with one year divided 812 into four seasons. 


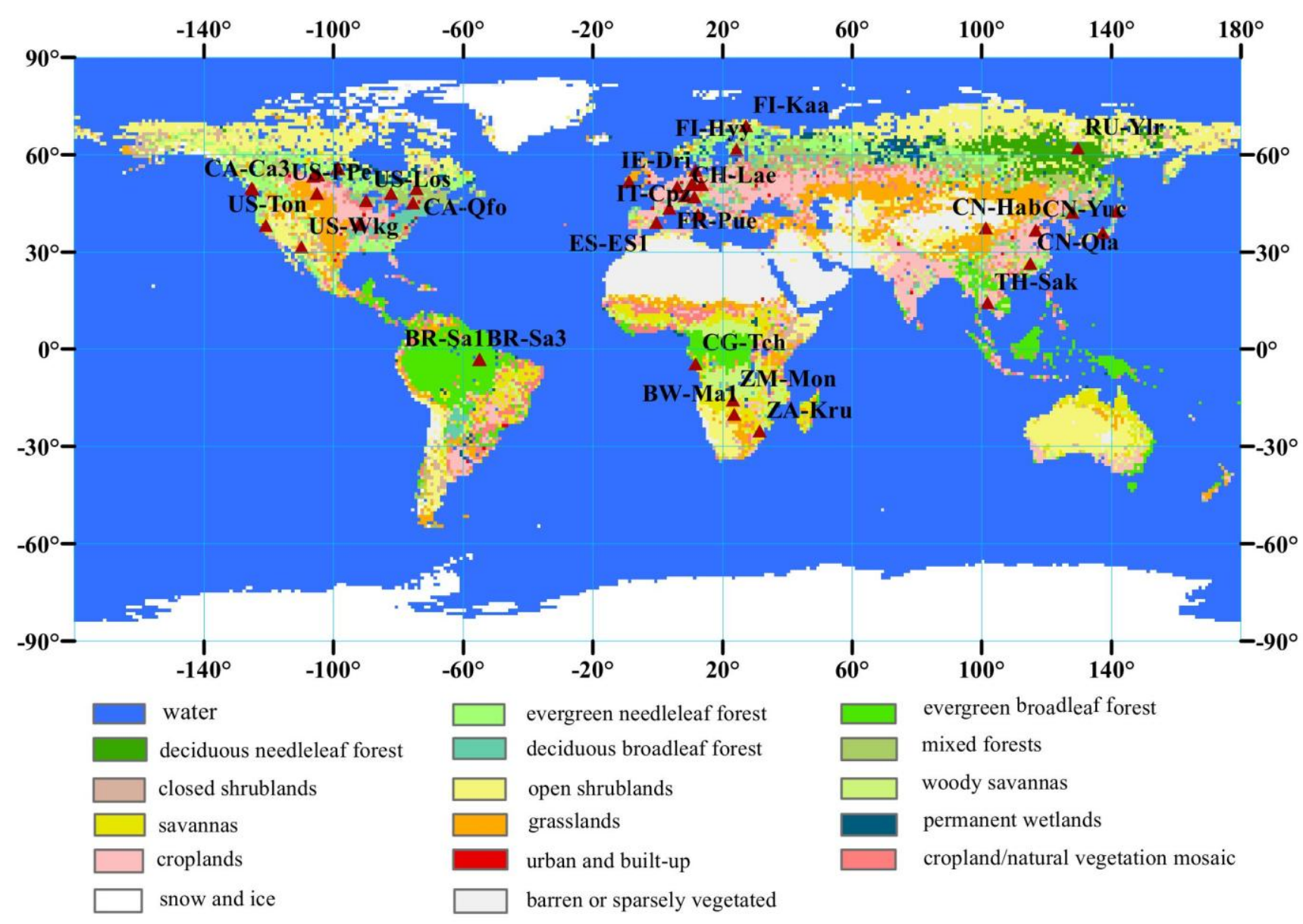

\section{Fig. 1.}

815 Spatial distribution of the 46 sites (for details see Table 1) at which measured GPP was used for

816 calibrating and validating the LUE models. The background is the synergetic global land cover map

817 (synGLC) based on Bayes theorem (Xu et al., 2014). 
(a) $\rightarrow$-Boreal-BDF $\rightarrow$ - Boreal-NDF $\rightarrow$-Mediterranean-BDF $\rightarrow$-Temperate-BDF $\rightarrow$ Tropical-BDF $\leftarrow$ Temperate-BDS $\rightarrow$-Boreal-BDS
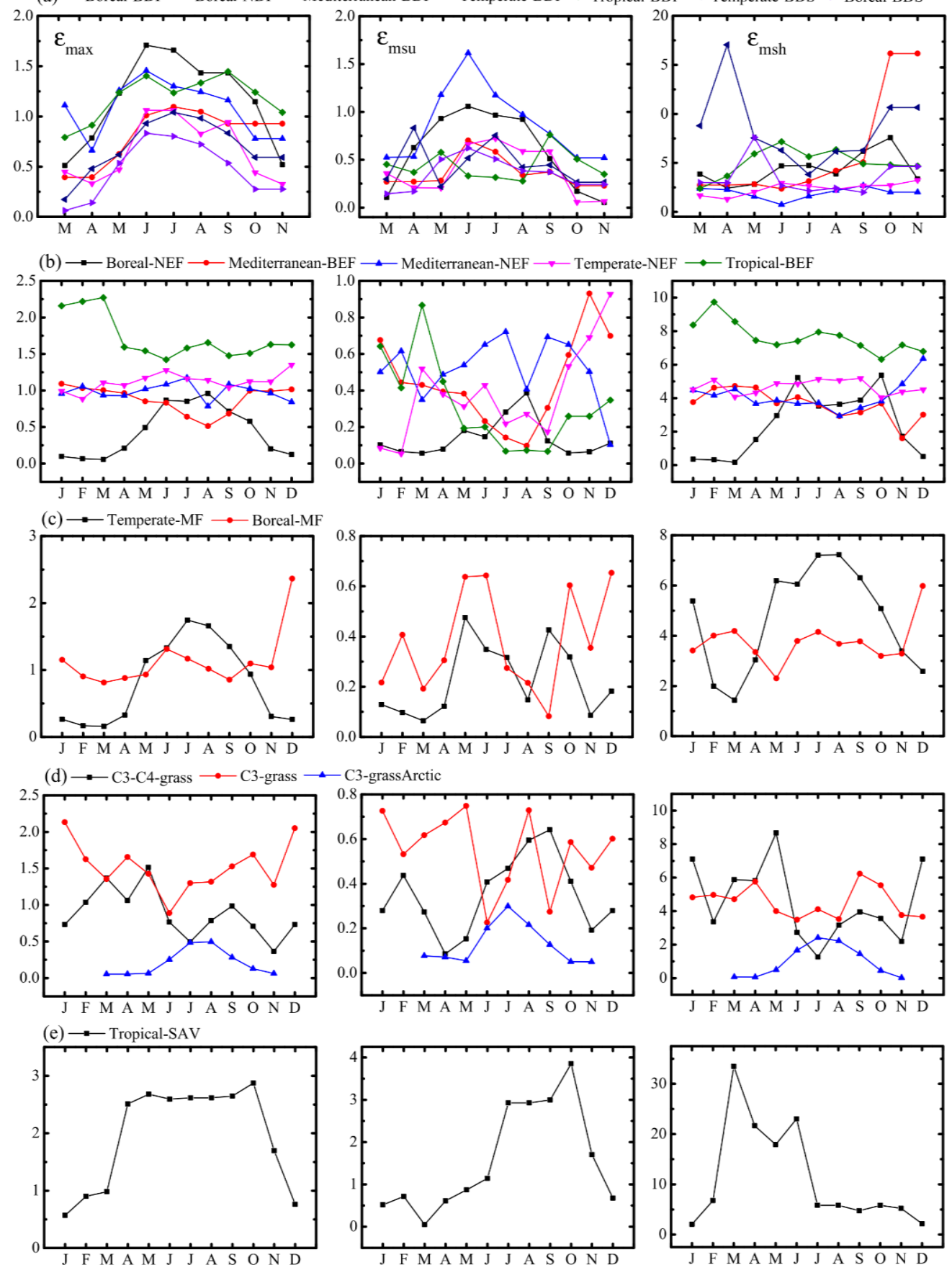

819 Fig. 2.

820 Posterior mean estimates for seasonal variation of the LUE parameters $\left(\varepsilon_{\max }, \varepsilon_{m s u}\right.$ and $\varepsilon_{m s h}$ from left to

821 right) given by the Bayesian approach based on in situ data for (a) deciduous forests and shrubs; (b)

822 evergreen forests; (c) mixed forests; (d) grassland; (e) savanna. Among them, from March to November

823 for deciduous vegetations, from January to December for other vegetations. 


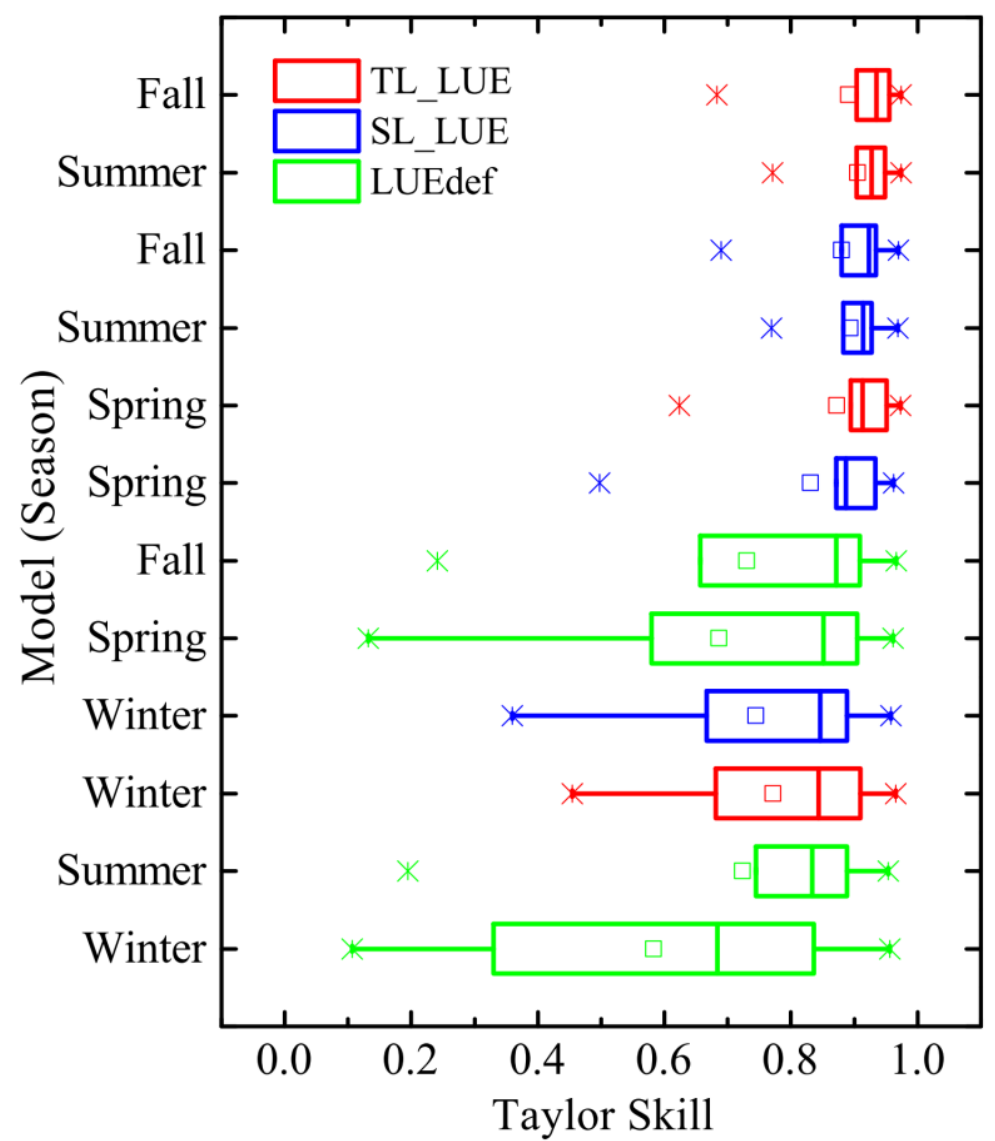

$825 \quad$ Fig. 3.

826 Boxplots of Taylor skill (S) for GPP by models and seasons (from Spring to Winter) across eighteen 827 plant functional types. Panels show the interquartile range (box), mean (square), median (solid line), 828 range (whiskers), and outliers (cross). The models and seasons are sorted by the median Taylor skill.
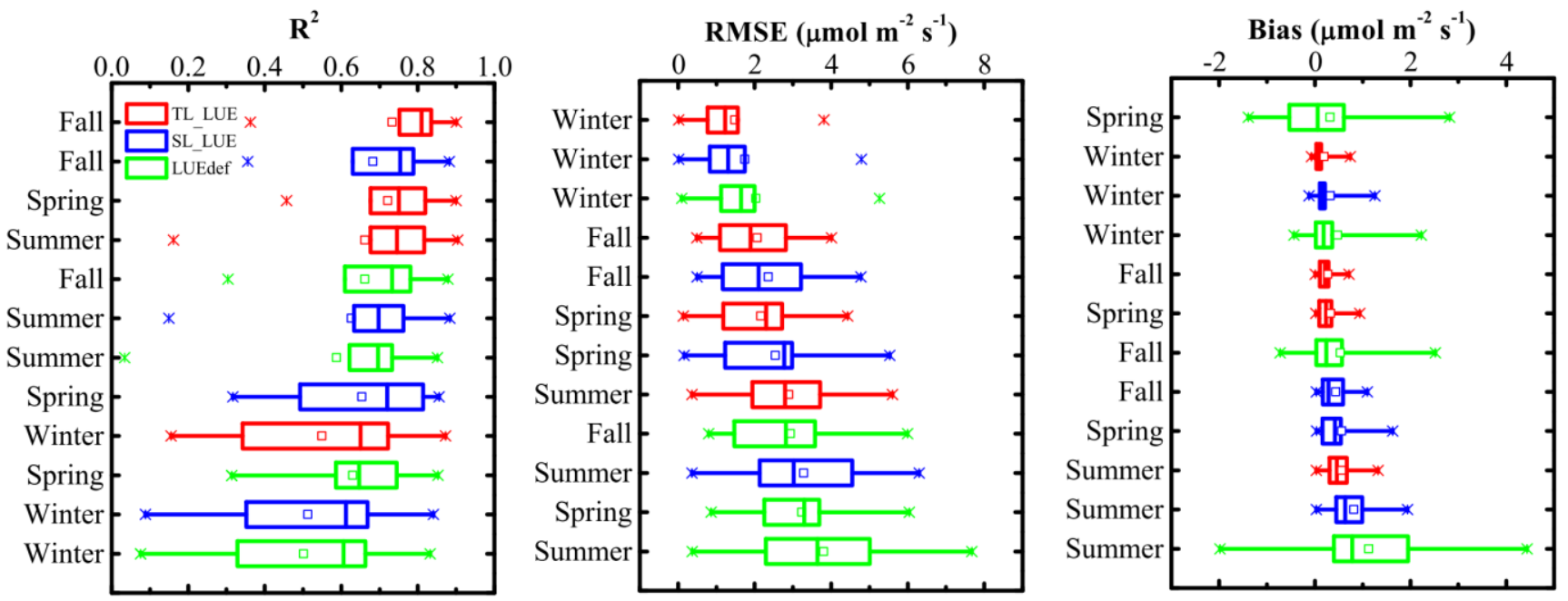
Fig. 4.

$832 \mathrm{R}^{2}$, root-mean-square error (RMSE) and Bias (observations minus simulations) of half-hourly GPP (in $833 \mu \mathrm{mol} \cdot \mathrm{m}^{-2} \cdot \mathrm{s}^{-1}$ ) with respect to individual season for one-leaf and two-leaf LUE models, respectively.

834 Panels show the interquartile range (box), mean (square), median (solid line), range (whiskers), and 835 outliers (cross). The models and seasons are sorted by the median.
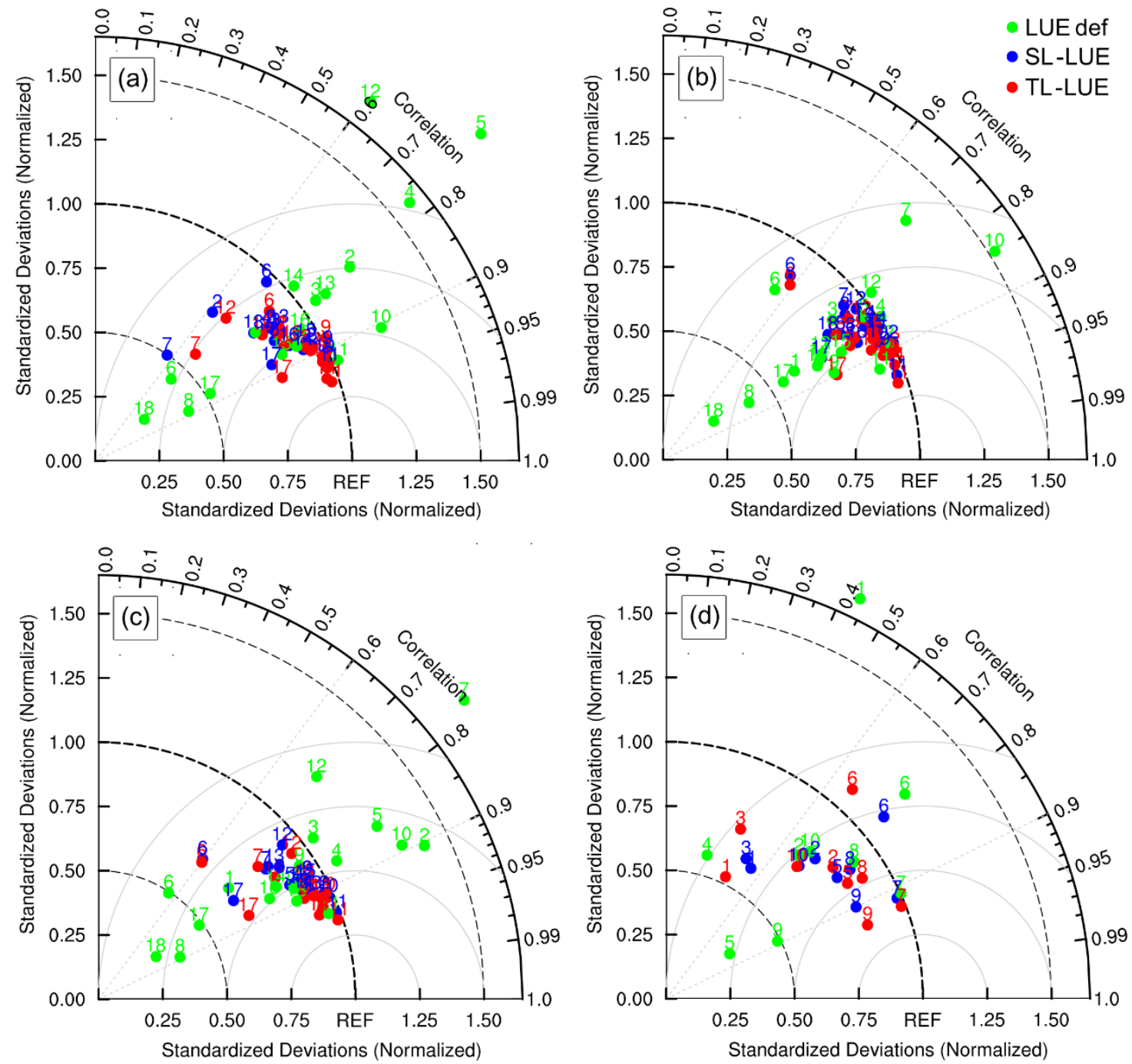

836

$837 \quad$ Fig. 5.

838 Comparing the models' performance for eighteen PFTs from spring to fall and ten PFTs in winter 839 (Table 2). The statistics in the Taylor diagram were calculated from the simulated (SL-LUE, TL-LUE, and $\mathrm{LUE}_{\mathrm{def}}$ ) and observed GPP values of the selected year for each plant functional type: (a) average 
841 values in spring, (b) average values in summer, (c) average values in fall and (d) average values in 842 winter. An ideal model has a standard deviation ratio $\left(\sigma_{\text {norm }}\right)$ of 1.0 and a correlation coefficient of 1.0 843 (REF, the reference point).

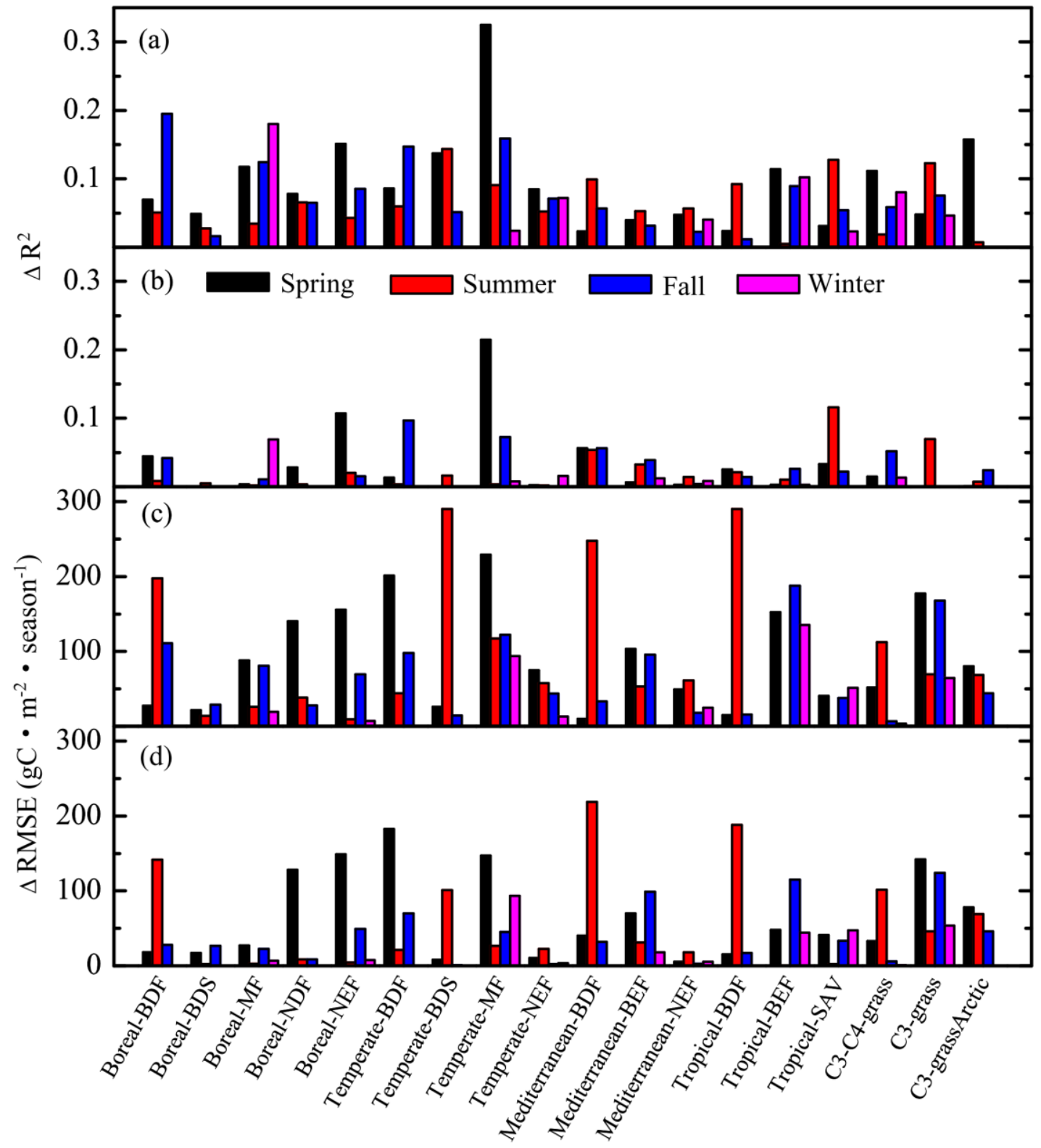

845 Fig. 6.

846 The improvement of GPP simulations after considering the seasonal variations of the maximum LUE

847 parameters for different PFTs. Pannels (a)-(b) represent the improvement of $\mathrm{R}^{2}$ with respect to 848 individual seasons for the one-leaf and two-leaf LUE models, respectively. Pannels (c)-(d) show the 
849 decrease of RMSE $\left(\mathrm{gC} \cdot \mathrm{m}^{-2} \cdot\right.$ season $\left.^{-1}\right)$ with respect to individual seasons for the one-leaf and two-leaf 850 LUE models, respectively. 
Deciduous forests and shrubs
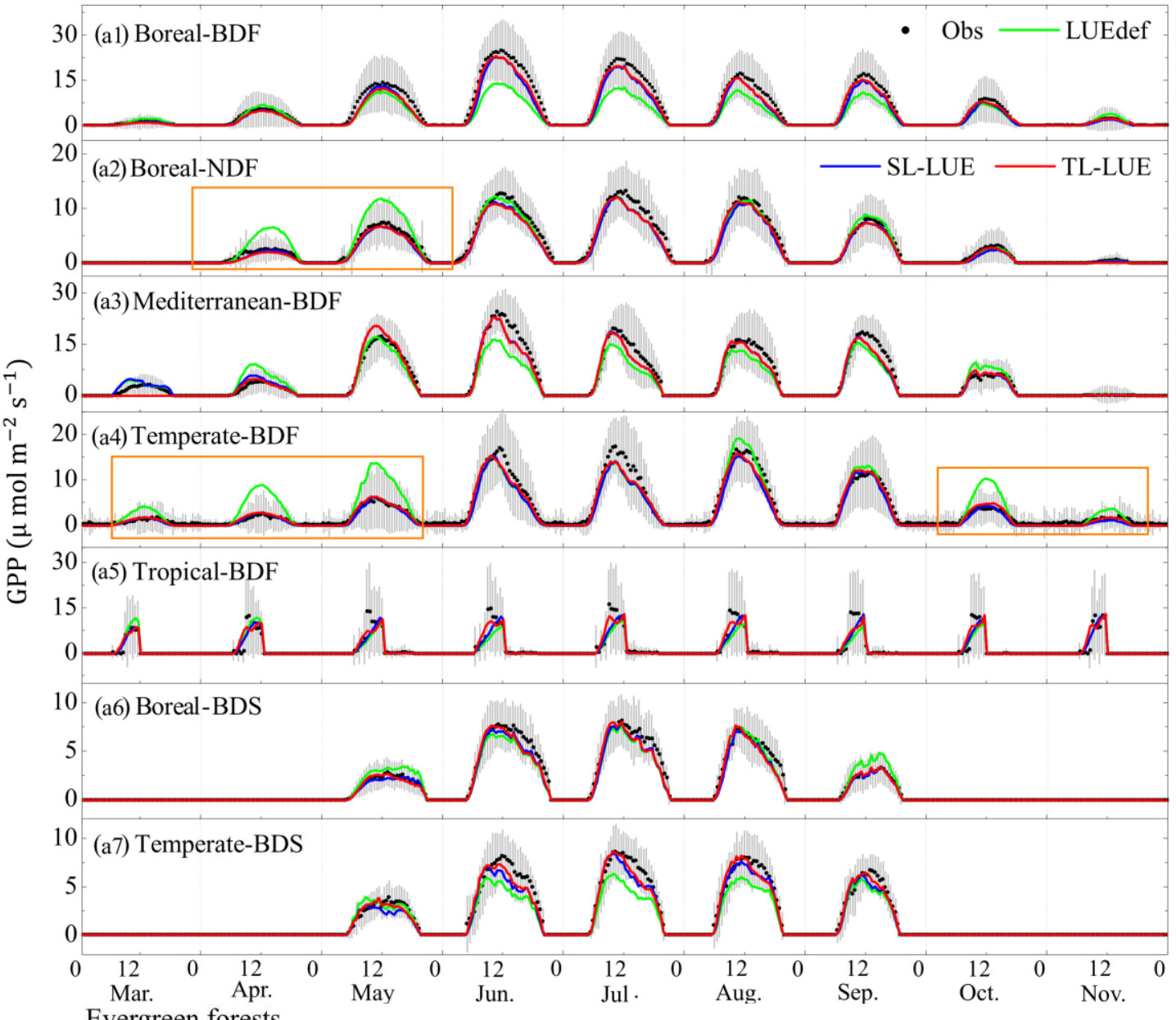

$$
15
$$

10 - (b1) Boreal-NEF

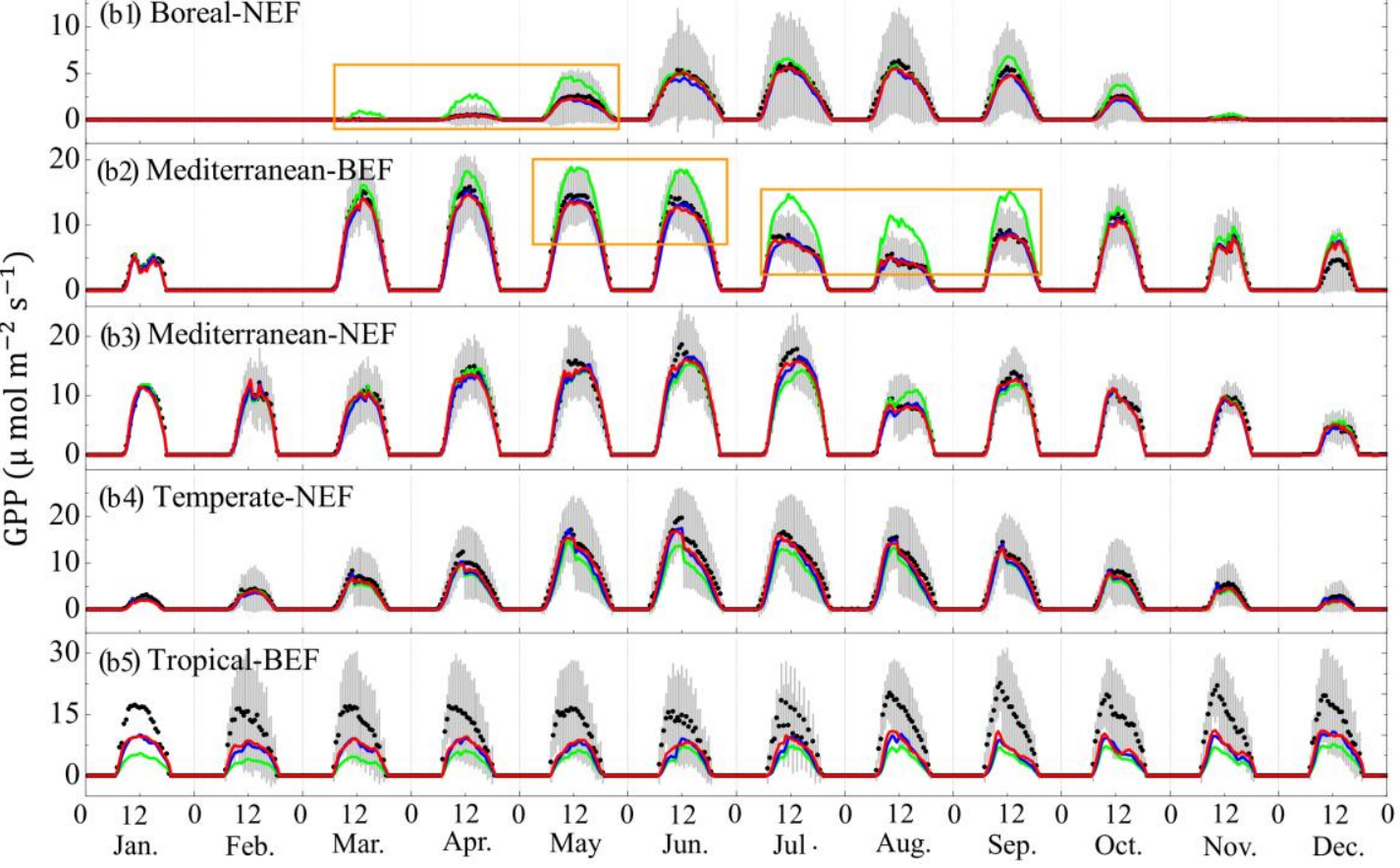



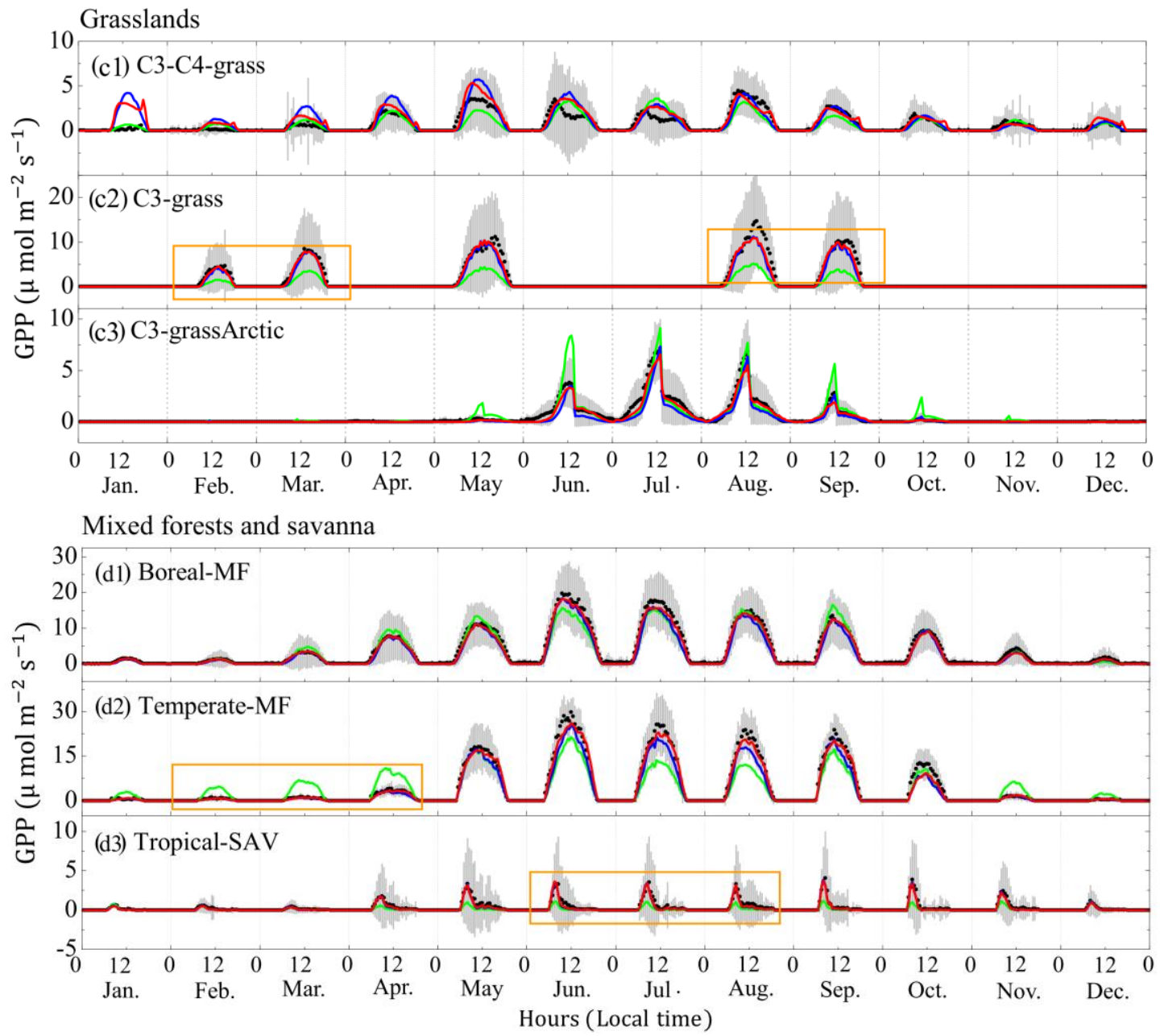

854

855 Fig. 7.

856 Monthly averaged diurnal composites of observed GPP (dark lines) and simulated GPP. The monthly-

857 averaged diurnal composites were calculated by accumulating the data of the same half-hourly point 858 over each month and then averaging. 

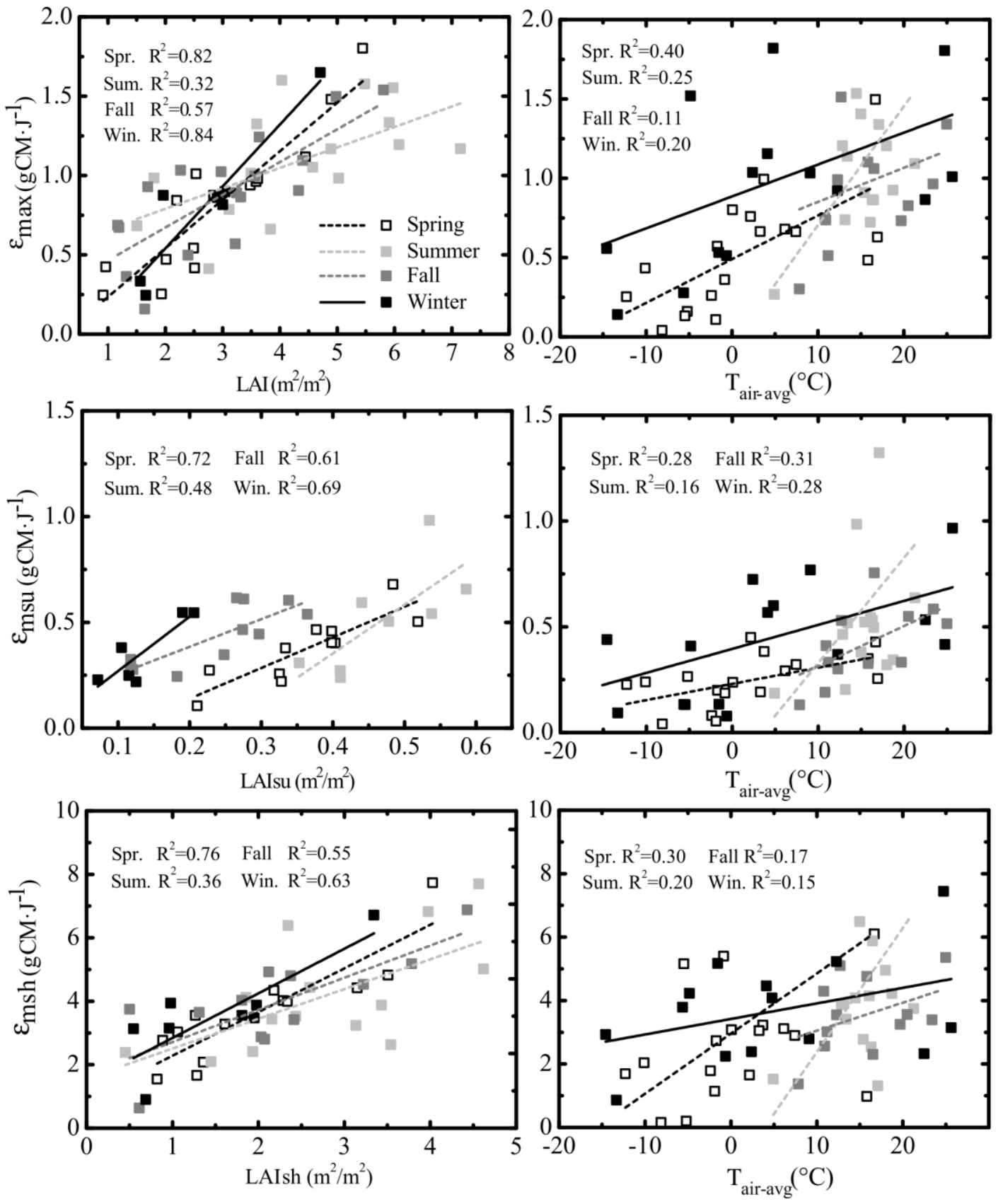

$860 \quad$ Fig. 8.

861 The seasonallye averaged LAI (LAI, $\mathrm{LAI}_{\text {su }}$ and $\left.\mathrm{LAI}_{\mathrm{sh}}, \mathrm{m}^{2} / \mathrm{m}^{2}\right)$ and ambient temperature $\left(\mathrm{T}_{\text {air-avg }},{ }^{\circ} \mathrm{C}\right)$

862 versus the optimized seasonal maximum LUE $\left(\varepsilon_{\max }, \varepsilon_{m s u}\right.$ and $\left.\varepsilon_{m s h}, \mathrm{gC} \cdot \mathrm{MJ}^{-1}\right)$ parameters for 18 PFTs,

863 respectively. 


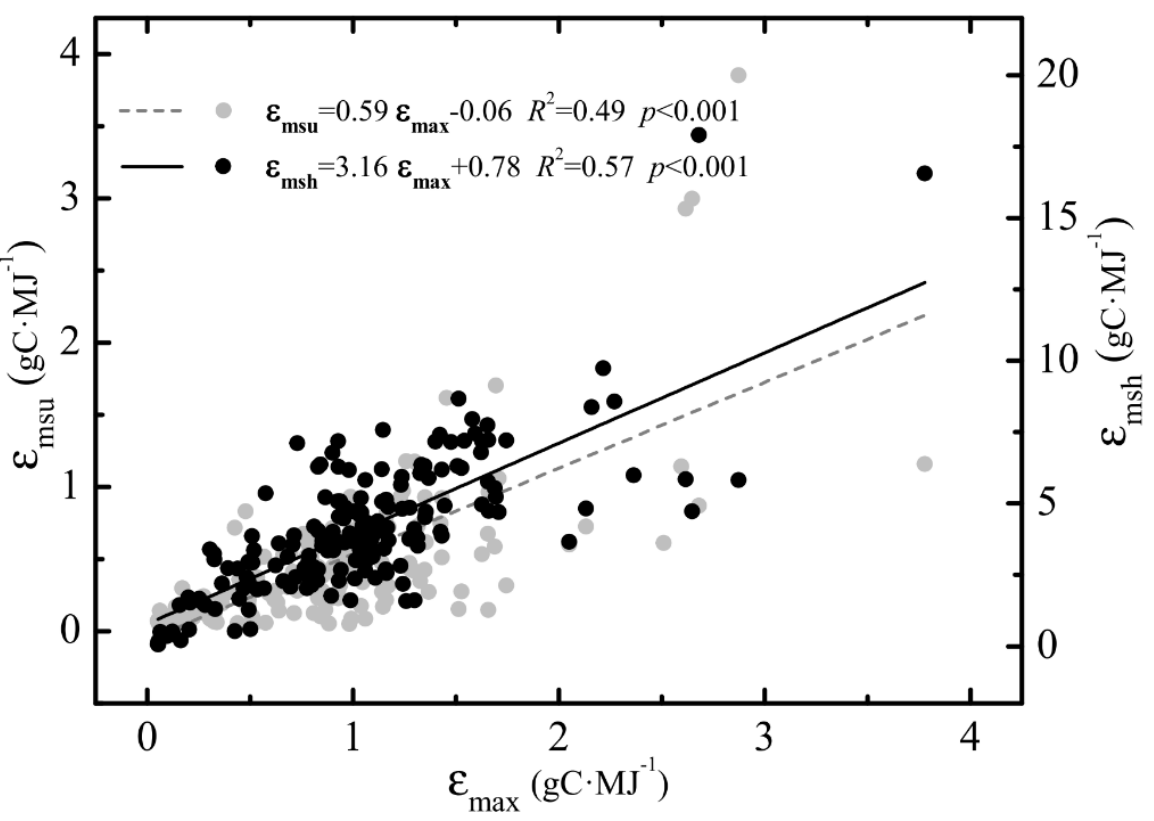

865 Fig. 9.

866 The optimized monthly maximum LUE $\left(\varepsilon_{\max }, \mathrm{gC} \cdot \mathrm{MJ}^{-1}\right)$ versus maximum LUE for sunlit and shaded 867 leaves ( $\varepsilon_{m s u}$ and $\varepsilon_{m s h}, \mathrm{gC} \cdot \mathrm{MJ}^{-1}$ ) for 18 different vegetation types. 